\title{
Interleukin-1 Receptor Antagonist in Normal and Psoriatic Epidermis
}

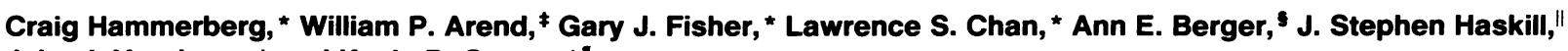 \\ John J. Voorhees, ${ }^{\star}$ and Kevin D. Cooper ${ }^{\star 1}$ \\ *Department of Dermatology, University of Michigan Medical School, Ann Arbor, Michigan 48109-0530; ${ }^{\ddagger}$ Department of Medicine, \\ University of Colorado School of Medicine, Denver, Colorado 80262; ${ }^{\S}$ Department of Cell Biology, The Upjohn Company, Kalamazoo, \\ Michigan 49001; "Lineberger Comprehensive Cancer Center, University of North Carolina, Chapel Hill, North Carolina 27599-7295; \\ and'Veterans Administration Medical Center, Ann Arbor, Michigan 48109
}

\begin{abstract}
The objective of these studies was to characterize the IL-1 inhibitory activity present in normal and psoriatic epidermis from clinically stable lesions. Fractionation of normal epidermal cytosol on a molecular sizing column failed to reveal the presence of IL-1 inhibitory bioactivity. However, specific ELISAs indicated that both the IL-1 receptor antagonist (IL-1ra) and IL$1 \alpha$ were present in overlapping peaks. Further fractionation of the normal epidermal cytosol by anion exchange chromatography separated these two molecules, revealing the IL-1 inhibitory bioactivity of the IL-1 ra molecule. Similar studies on psoriatic epidermal cytosol indicated the presence of IL-1 inhibitory bioactivity and IL-1ra protein. The IL-1 inhibitory bioactivity of both normal and psoriatic cytosol was neutralized by a mAb specific for IL-1ra. The ratio of IL-1ra to IL-1 $\alpha$ proteins was significantly increased in involved psoriatic skin compared with normal skin. By Western blot analysis this IL-1 ra was $\approx 20$ kD, slightly larger than monocyte-derived IL-1 ra and equivalent to an intracellular variant of IL-1 ra expressed by keratinocytes. Polymerase chain reaction indicated the presence of mRNA for both forms of IL-1 ra in normal epidermis, with both forms increased in psoriatic-involved skin. Immunofluorescence studies revealed the IL-1ra protein to be concentrated in the stratum granulosum of normal skin and in the basal-midbasal layers of psoriatic epidermis. These results suggest that the balance between intracellular IL-1 ra and IL-1 $\alpha$ may be an important influence on keratinocyte growth and/or differentiation, as well as on the inflammatory potential of IL-1 in injured skin. (J. Clin. Invest. 1992. 90:571-583.) Key words: IL-1 $\alpha$ • IL-1 $\beta \cdot$ homeostasis $\bullet$ differentiation $\bullet$ keratinocyte
\end{abstract}

\section{Introduction}

The skin is a major reservoir of IL-1 $(1,2)$ because of constitutive production by keratinocytes $(3,4)$ and sweat gland epithelium (5). IL-1 is capable of inducing cutaneous inflammation

This work was represented in abstract form at the FASEB (Federation of American Societies for Experimental Biology) meeting in Atlanta, GA, 21-25 April 1991, and at the national meeting of the Society for Investigative Dermatology, Seattle, WA, 1-4 May 1991.

Address reprint requests to Craig Hammerberg, Ph.D., Department of Dermatology, University of Michigan Medical School, R5548 Kresge I/0530, Ann Arbor, MI 48109-0530.

Received for publication 13 August 1991 and in revised form $28 \mathrm{Feb}$ ruary 1992

J. Clin. Invest.

(C) The American Society for Clinical Investigation, Inc. 0021-9738/92/08/0571/13 \$2.00

Volume 90, August 1992, 571-583 upon injection into human skin (6) and is released from the epidermal cells after ultraviolet (UV) radiation (7-9). Epidermal IL-1 release not only recruits an inflammatory response, but also potentiates $T$ cell subset activation and the nature of the subsequent inflammatory response (10). The mechanisms by which the inflammatory potential of the large amounts of IL- 1 contained in the epidermis are restrained may be due in part to the inability of keratinocytes to effectively proteolyse inactive IL- $1 \beta$ precursor molecules (11), such that human epidermis contains inactive IL- $1 \beta$ that has been processed into novel informs of the molecule (12). IL- $1 \alpha$, which is active in vivo in both the precursor and processed forms, remains intracellular in unstimulated keratinocytes (13). Thus, the role of IL-1 in skin and its regulation in cutaneous homeostasis in vivo remain poorly understood.

A skin condition that may provide clues to the involvement of IL-1 in skin biology is psoriasis. IL-1 has the ability to cause cutaneous inflammation (6), potentiate $T$ cell activation (14), stimulate eicosanoid metabolism (15), induce fibroblast proliferation (16), upregulate endothelial cell adhesion molecule expression $(17,18)$, and potentially stimulate keratinocyte proliferation $(19,20)$. Because each of these elements may be present in psoriatic skin (21-28), overexpression of IL-1 has been postulated as a possible trigger for this disease process. However, the growth-promoting capacity of IL-1 for human keratinocytes has been called into question (29) and IL-1 activity is markedly reduced in psoriatic skin (30). Despite existing in a processed form, epidermal IL- $1 \beta$ was incapable of activating a murine $\mathrm{T}$ cell line expressing the type I IL-1 receptor or of activating murine thymocytes (30). The nonfunctionality of the IL- $1 \beta$ in concert with a 14 -fold decrease in IL- $1 \alpha$ levels are consistent with the reduced levels of IL-1 activity in psoriatic keratome extracts (30). Further complexity was added to the situation on finding that an inhibitor of IL-1 activity also contributed to the markedly reduced bioactivity of IL-1 in psoriatic lesions (30). This inhibitor was not secreted constitutively, had a molecular mass of $\sim 30 \mathrm{kD}$ and an isoelectric point of 5.3 and was distinct from transforming growth factor $\beta$ $(\mathrm{TGF} \beta)^{1}(31)$.

Recently, a specific human IL-1 receptor antagonist (IL$1 \mathrm{ra}$ ) has been purified from the supernatants of IgG-stimulated monocytes (32) and from the myelomonocytic leukemia cell line U937 after induction of differentiation (33). The IL-1 ra molecule was sequenced and is a single peptide of 152 amino acids that exists in both $17-\mathrm{kD}$ nonglycosylated and 22-25-kD

1. Abbreviations used in this paper: DPBs, Dulbecco's modified PBS; FPLC, fast protein liquid chromatography; IL-1 ra, interleukin-1 receptor antagonist; PCR, polymerase chain reaction; TGF $\beta$, transforming growth factor $\beta$. 
glycosylated forms with a pI of $5.0(32,33)$. IL-1 ra has $30 \%$ amino acid sequence homology to IL-1 $\beta$ and $19 \%$ homology to IL- $1 \alpha$. Complementary DNAs have been cloned and expressed in Escherichia coli with production of recombinant 17-kD IL1 ra molecules that retain full biological activity (32-34). IL$1 \mathrm{ra}$ appears to be a true receptor antagonist in that it competitively binds to the type I IL-1 receptor on T cells $(32,33)$, endothelial cells (33), fibroblasts (32), synovial cells, and chondrocytes (35) and the human type II IL-1 receptor on B cells and polymorphonuclear leukocytes $(36,37)$ without inducing detectable cellular responses.

The mRNA for a structural variant of monocyte-derived IL-1 ra has recently been described in cultured keratinocytes and other epithelial cells (38). The cDNA clones derived from both monocytes and cultured keratinocytes predict that this mRNA encodes for a protein that is identical to mature $17-\mathrm{kD}$ monocyte IL-1 ra except for the presence of an additional seven $\mathrm{NH}_{2}$-terminal amino acids and the lack of a leader peptide for secretion. Cultured keratinocytes produce a large quantity of IL-1'ra that remains entirely intracellular (icIL-1 ra) and is slightly larger in size than $17-\mathrm{kD}$ monocyte IL-1 ra protein ( sIL1 ra) $(38,39)$. IL-1 ra production by cultured keratinocytes increases with cell differentiation (39).

The purpose of the present studies was to examine freshly obtained human skin from normal subjects to determine whether IL-1 ra is produced in vivo by epidermal keratinocytes. Furthermore, we wanted to determine if the IL-1 inhibitory activity that dominates in psoriatic epidermis could be attributed to expression of IL-1 ra. Cytosolic extracts of keratome biopsies were fractionated by both gel filtration and ion exchange chromatography. The fractions were analyzed for IL-1 inhibitor bioactivity, both IL-1 ra and IL- $1 \alpha$ proteins by specific ELISAs, and neutralization of functional activity with specific antibodies. In addition, IL-1 ra was localized in intact skin by immunofluorescence techniques and the presence of mRNA transcripts within the epidermis were identified by polymerase chain reaction (PCR). Our results raise the possibility that IL$1 \mathrm{ra}$ is important for cutaneous homeostasis not only by limiting the inflammatory effects of extracellular IL-1 in injured skin, but also by limiting putative intracellular actions of IL-1.

\section{Methods}

Materials. Polyethylene glycol (PEG, mol wt 8,000), sucrose, Tris, 3-(4,5-dimethylthiazol-2-yl)-2,5-diphenyltetrazolium bromide, MOPC21, Tween 20, and PMSF were obtained from Sigma Chemical Co. (St. Louis, MO). PHA was obtained from Wellcome Diagnostics (Dartford, England). DTT was purchased from Bio-Rad Laboratories (Rockville Center, NY). The Fast Protein Liquid Chromatography (FPLC) apparatus and Mono $Q$ anion exchange column were purchased from Pharmacia Inc. (Piscataway, NJ). A TSK G2000SW molecular sizing column was obtained from Toyo Soda ( Tokyo, Japan ). A rabbit antiserum and a mAb to IL- $1 \alpha$ used in the ELISA and human recombinant IL- $1 \alpha$ were gifts from Dainippon Pharmaceutical Corp. (Osaka, Japan). Human recombinant IL-1 $\beta$ was purchased from Cistron Corp. (Pine Brook, NJ). Rabbit polyclonal antiserum to IL-1 ra was prepared and characterized as previously described $(32,40)$. Hybridomas secreting $\mathrm{mAbs}$ to the IL-1 ra protein were derived using described techniques (41). The spleen cell donors were $\mathrm{CAF}_{1}$ mice that had been injected four times with 5-20 $\mu \mathrm{g}$ purified or recombinant IL-1 ra. None of the resulting mAbs, I.4, I.5 and I.10, reacted with human IL- $1 \alpha$ or IL- $1 \beta$ in ELISAs. These mAbs and the human recombinant IL-1ra protein were provided by The Upjohn Company. The $\mathrm{mAb}$ to TGF $\beta 1$ was obtained from Collagen Corp. (Palo Alto, CA).
Peroxidase-conjugated goat anti-rabbit IgG antibodies, goat antimouse IgG-biotin conjugate and goat anti-mouse IgG rhodamine-B conjugate were obtained from Tago Inc. (Burlingame, CA). Streptavidin-horseradish peroxidase conjugate was from Bethesda Research Laboratories (Gaithersburg, MD). Keratinocyte culture medium (modified MCDB 153) was formulated as described (42).

Preparation of keratome and keratinocyte cytosols. Keratome biopsies were obtained from lesional psoriatic plaques, clinically uninvolved psoriatic skin, and skin of normal subjects. Patients with psoriasis in this study had clinically stable plaques of sufficient size to enable two $10-\mathrm{cm}^{2}$ strips to be biopsied. The patients were off active therapy (except for bland emollients) for $\geq 1$ wk before the biopsy. The biopsies from both normal and psoriatic skin were performed on the hips or buttocks using a Castro Viejo keratome set (Storz Co., St. Louis, MO) at $0.2-0.3 \mathrm{~mm}$. Keratome strips were immediately snap frozen in liquid nitrogen. Keratomes were pulverized under liquid nitrogen. Dulbecco's PBS (DPBS, $\mathrm{Ca}^{++}$- and $\mathrm{Mg}^{++}$-free) with $1 \mathrm{mM}$ PMSF and $0.03 \%$ PEG was added at $100 \mathrm{mg}$ keratome wet $\mathrm{wt} / \mathrm{ml}$ buffer for samples to be examined by FPLC; DPBS plus $5 \mathrm{mM}$ DTT were added if cytosolic IL-1 ra and IL- $1 \alpha$ levels were to be measured directly in an ELISA. After homogenization with a glass homogenizer, cytosols were obtained by ultracentrifugation $(100,000 \mathrm{~g}, 60 \mathrm{~min})$ and the supernatants were sterile filtered and stored at $-70^{\circ} \mathrm{C}$.

Cytosols were prepared from cultured adult human keratinocytes grown from keratomes in modified MCDB 153 by washing the monolayer three times with $\mathrm{HBSS}\left(\mathrm{Ca}^{++}\right.$- and $\mathrm{Mg}^{++}$-free) and then scraping the cells off in the presence of DPBS with $1 \mathrm{mM}$ PMSF and $0.03 \%$ PEG. After three cycles of freeze thawing, cells were sonicated, ultracentrifuged $(100,000 \mathrm{~g}, 60 \mathrm{~min})$, and the supernatant stored at $-70^{\circ} \mathrm{C}$. Protein concentrations of keratomes and cytosols were determined by a protein assay kit (Bio-Rad Laboratories).

FPLC. $2 \mathrm{ml}$ of keratome cytosol were applied to a TSK G2000SW column equilibrated with DPBS plus $0.03 \%$ PEG. The flow rate was 3.0 $\mathrm{ml} / \mathrm{min}$ and 2.0-ml fractions were collected. Each fraction was sterilized by passage through a $0.2-\mu \mathrm{m}$ millipore filter and assayed for the presence of IL- $1 \alpha$ protein, IL-1 inhibitory activity, and IL-1 ra protein.

Keratome cytosols were dialyzed against $0.025 \mathrm{M}$ Tris ( $\mathrm{pH} 7.6$ ) with $0.1 \%$ sucrose before application to a Mono $Q$ column equilibrated with $0.025 \mathrm{M}$ Tris ( $\mathrm{pH} 7.6$ ) plus $0.1 \%$ sucrose. Samples were eluted with a $\mathrm{NaCl}$ gradient ranging from 0 to $250 \mathrm{mM} \mathrm{NaCl}$ at a rate of 0.5 $\mathrm{ml} / \mathrm{min}$ and $1-\mathrm{ml}$ fractions were collected. Fractions were dialyzed against DPBS, then sterile filtered, and assayed for the presence of IL-1 $\alpha$ protein, IL-1 inhibitory activity, and IL-1 ra protein.

$I L-1 \alpha E L I S A$. Immunoreactive IL- $1 \alpha$ in samples was quantified by using an ELISA as previously described (30). Standard curves of recombinant human IL- $1 \alpha$ ranging from 20 to $1,000 \mathrm{pg} / \mathrm{ml}$ were run for each assay. The sensitivity of the IL- $1 \alpha$ ELISA was $10 \mathrm{pg} / \mathrm{ml}$.

IL-1 inhibitor assay. IL-1 inhibitory activity was measured by blocking the production of IL-2 by LBRM.33 cells in response to IL-1 and PHA as previously described (31). Keratome cytosols or fractions from either the TSK G2000SW or Mono Q columns were tested for IL-1 inhibitory activity. Quantitation of the amount of IL-1 produced by LBRM. 33 cells was made in relation to an IL-2 standard curve that covered a range of 2-250 U/ml of activity. Maximal response of the LBRM.33 sample was compared with the standard curve to obtain the amount of IL-2 units per milliliter.

IL-1 ra ELISA. IL-1 ra protein was measured using a sandwich ELISA recently described in detail (40). The primary antibody in this ELISA was affinity-purified polyclonal rabbit antibodies specific for IL-1 ra. The secondary antibody was the IgG fraction of this antiserum coupled to biotin, followed by streptavidin peroxidase conjugate and 2,2'-azino-bis(3-ethylbenzthiazoline-6-sulfonic)acid (ABTS) solution. The sensitivity of this ELISA was $<200 \mathrm{pg} / \mathrm{ml}$ and the ELISA failed to recognize up to $100 \mathrm{ng} / \mathrm{ml}$ of IL- $1 \alpha$ or IL- $1 \beta$. The recombinant human IL-1 ra standard was provided by Dr. Robert C. Thompson, Synergen Inc., Boulder, $\mathrm{CO}$.

IL-1ra indirect immunofluorescence. mAbs to IL-1 ra (I.4 and I.10 ascites) or isotype control MOPC21 ascites were diluted 1:100 or 1:200 
and reacted with acetone-fixed 6- $\mu \mathrm{m}$ sections of human skin-punch biopsies frozen in O.C.T. compound (Miles Inc., Elkhart, IN) as previously described (43). To test whether soluble recombinant IL-1 ra protein would inhibit the binding of mAbs to the skin sections, a 1:200 dilution of antibody I. 4 was preincubated with recombinant IL-1 ra ( 10 $\mu \mathrm{g}$ ) at $37^{\circ} \mathrm{C}$ for $1 \mathrm{~h}$. The antibody-antigen mixture was then centrifuged in a microfuge at $4^{\circ} \mathrm{C}$ for $15 \mathrm{~min}$ and the supernatants were used to react with the skin sections as described above.

IL-Ira neutralization assay. $50 \mu \mathrm{l}$ of $\mathrm{mAb}$ ascites against IL-1 ra (I.10, murine $\mathrm{IgG}_{1}$ isotype) was added to 96 -well flat-bottom tissue culture plates and preincubated with $50 \mu \mathrm{l}$ of TSK G2000SW or Mono Q IL-1 inhibitory fractions for $2 \mathrm{~h}$ at $37^{\circ} \mathrm{C}$. As an isotype control, 1D.116, an $\mathrm{IgG}_{1}$ murine $\mathrm{mAb}$ against TGF $\beta 1$ (44), was added at the same dilutions as mAb I.10.25 $\mu$ l of PHA ( $2 \mu \mathrm{g} /$ well $),$ LBRM.33 cells $\left(10^{5}\right.$ cells/well $)$ and $50 \mu \mathrm{l}$ of rIL-1 $\beta(0.25$ or $2.5 \mathrm{U} /$ well $)$ were then added and incubated for $24 \mathrm{~h}$ at $37^{\circ} \mathrm{C}$. The IL-1 inhibitor assay was then continued as described above.

Immunoblotting. Human epidermis or keratinocyte cytosol were concentrated 5-10-fold with a Centricon 3 system (3,000 mol wt cut off) (Amicon Division, W. R. Grace Co., Beverly, MA) and samples were electrophoresed on a $12 \%$ SDS-PAGE gel and Western blotted as described previously (43). After reaction with a mAb to IL-1 ra (I.5) or a myeloma isotype ascites control (MOPC 21), the nitrocellulose membrane was reacted with a goat anti-mouse IgG biotin conjugate followed by a streptavidin-horseradish peroxidase conjugate. The presence of the immune complex was detected using chemiluminescence (ECL Western blotting detection system and Hyperfilm; Amersham International, Arlington Heights, IL).

IL-1 ra mRNA in normal and psoriatic skin. PCR was used to determine the presence of mRNA for sIL- $1 \mathrm{ra}$, icIL- $1 \mathrm{ra}$, and IL- $1 \beta$ in normal and psoriatic skin. Total RNA was prepared from normal and clinically stable psoriatic keratomes by using RNAzol (Tel-Test, Inc., Friendswood, TX). Total RNA from monocytes was prepared as previously described (38). RNA was reverse-transcribed into cDNA using random hexamers as primers and PCR performed essentially as reported (45). PCR primer pairs specific for icIL-1 ra and sIL-1 ra were those used by Haskill et al. (38) and those for IL- $1 \beta$ were described by Wang et al. (46). A standard curve, which ranged from 14 to 0.014 $\mathrm{pg} / \mu \mathrm{l}$, was constructed for each PCR product using plasmid containing a cDNA insert of the appropriate protein. PCR products were determined at 24,26 , and 28 cycles, but only data from 28 cycles are shown. That the PCR products are from the correct sequence was confirmed by repeating PCR upon the PCR products with primer pairs internal to the original sequence. Ethidium bromide-stained gels were photographed on an UV light box with Polaroid type 55 positive/negative film. The negative was rinsed in water, dried, and analyzed with a Laser Densitometer (LKB Instruments, Gaithersburg, MD).

Statistical analysis. After log transformation of the ratio of IL-1 ra and IL- $1 \alpha$ protein levels in the different samples, the mean of the individual ratios of the involved psoriatic epidermis was compared with the mean of the ratios of uninvolved psoriatic or normal epidermis by univariate one-way analysis of variance.

\section{Results}

IL-1ra in normal epidermal cytosol. To determine whether IL1 inhibitory activity was present in in vivo epidermis of normal skin, keratome cytosols were assayed for inhibition of IL- $1 \beta$ stimulation of LBRM.33 cells. At a cytosol concentration of 3 $\mu \mathrm{g} / \mathrm{ml}$, IL-1 activity was detected (Fig. 1). However, at a higher cytosol concentration ( $13 \mu \mathrm{g} / \mathrm{ml})$, IL-1 activity disappeared. This result suggested the presence of an IL-1 inhibitor. Indeed, when a suboptimal concentration of recombinant IL$1 \beta$ was added to LBRM.33 cells in the presence of human keratome cytosols, additive IL-1 bioactivity was observed at 0.4 and $3 \mu \mathrm{g} / \mathrm{ml}$. However, inhibition of the IL-1-induced pro-

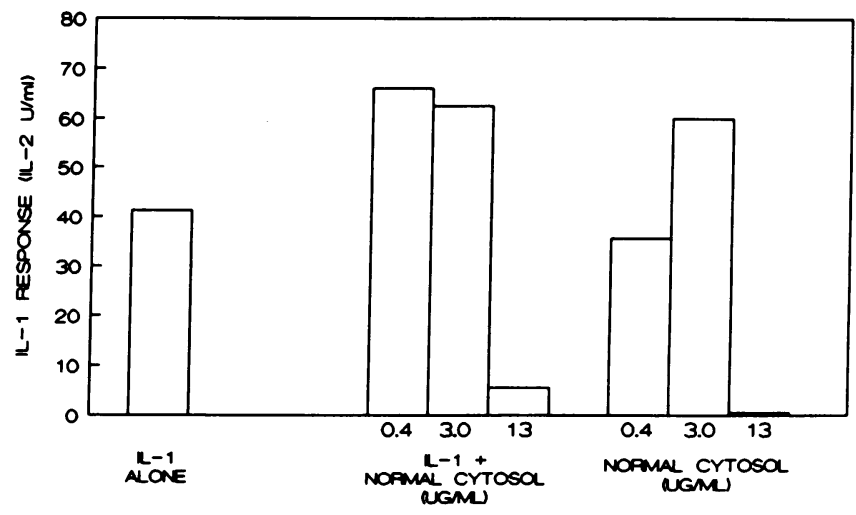

Figure 1. Both IL-1 and IL-1 inhibitory activities are present in keratome cytosol from normal human skin. The data are expressed as $\mathrm{U} / \mathrm{ml}$ of IL-2 produced by LBRM.33 cells stimulated with normal keratome cytosol in the presence or absence of a suboptimal concentration of IL- $1 \beta$. The first bar indicates IL-1 activity of $0.25 \mathrm{U} / \mathrm{ml}$ IL- $1 \beta$ alone. Bars 2-4 show the detected levels of IL- 1 activity where $0.25 \mathrm{U} / \mathrm{ml} \mathrm{IL-1} \beta$ was added to each of the indicated amounts of keratome cytosol. Bars 5-7 indicate the levels of IL-1 activity present in the normal keratome cytosol alone.

duction of IL-2 occurred at a keratome cytosol protein concentration of $13 \mu \mathrm{g} / \mathrm{ml}$ (Fig. 1). This finding suggests that either a critical concentration of an IL-1-specific inhibitor must be achieved to detect its function or that the keratome cytosols contain a complex mixture of nonspecific and IL-1-specific inhibitory and costimulatory factors.

To ascertain whether IL-1 ra was present in the epidermal cytosol, we used FPLC fractionation on a TSK G2000SW molecular sizing column to separate nonspecific inhibition from IL-1-specific inhibitors. Although partial inhibition by a variety of fractions was found, the presence of IL-1 inhibitory activity that could completely suppress the IL-1 induction of IL-2 production by LBRM.33 cells was not revealed (Fig. $2 A$ ). However, when an ELISA specific for IL-1 ra was performed on the same fractions, IL-1 ra protein was detected in fractions coeluting at $\sim 30 \mathrm{kD}$ (Fig. $2 \mathrm{~B}$ ). Elution profiles of ELISA-detectable precursor and processed forms of IL- $1 \alpha$ demonstrated that both partially overlapped the IL-1 ra peak, although they eluted slightly before and after the IL-1 ra protein, respectively (Fig. 2 C). However, LBRM.33 cells are relatively insensitive to the antagonist effect of the IL-1 ra protein, a ratio in excess of 500:1 (IL-1 ra:IL- $1 \alpha$ ) is required to obtain complete suppression of IL-1 induction of IL-2 production (data not shown) (33). Thus, the apparent absence of IL-1 inhibitory biological activity in the TSK G2000SW fractions may be due to the presence of IL- $1 \alpha$ molecules, which were also present in the same fractions containing IL-1 inhibitory activity (Fig. $2 \mathrm{C}$ ).

Because the presence of IL- $1 \alpha$ in the same fractions as the ELISA-detectable IL-1 ra protein on gel-filtration chromatography might mask IL-1 inhibitory activity, cytosol from normal epidermis was fractionated on an anion exchange Mono $Q$ column (Fig. 3). This fractionation now clearly revealed the presence of IL-1 inhibitory activity that eluted between 85 and 95 $\mathrm{mM} \mathrm{NaCl}$ (Fig. $3 A$ ). The peak of IL-1 inhibitory activity coeluted with ELISA-detectable IL-1 ra protein (Fig. $3 B$ ). Additional ELISA-detectable IL-1 ra protein was present in later fractions without any corresponding IL-1 inhibitory activity. This result could be explained by the presence of small 
A

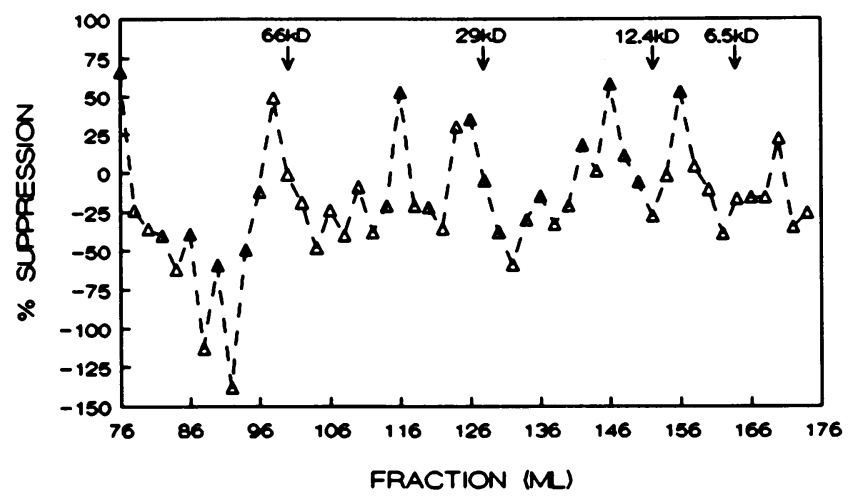

B

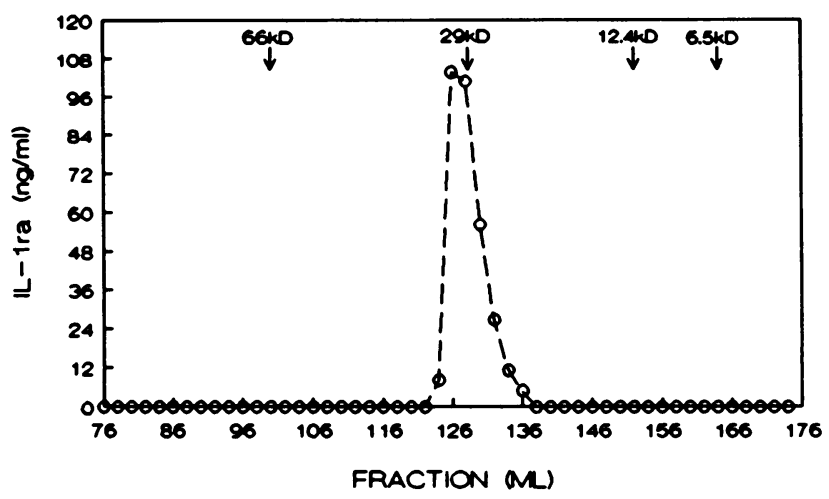

C

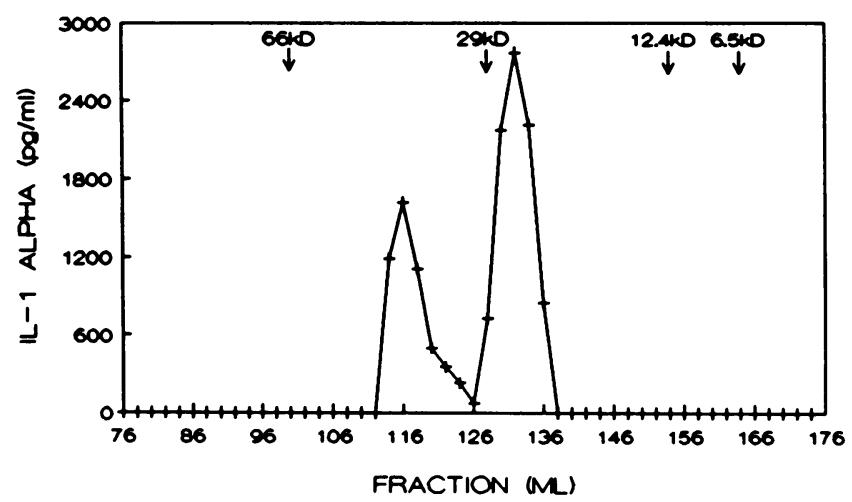

Figure 2. IL-1 $\alpha$ and IL-1 ra proteins are both present in normal keratome cytosol. The cytosol was fractionated by a FPLC TSK

G2000SW sizing column. Fractions were assayed for $(A)$ IL-1 inhibitor bioactivity (percent suppression of IL-1 effects on LBRM.33 cells), $(B)$ IL-1 ra protein ( $\mathrm{ng} / \mathrm{ml}$ by ELISA), and $(C)$ IL- $1 \alpha$ protein (pg/ml by ELISA).

amounts of IL- $1 \alpha$ in these fractions eluting at high salt concentrations (Fig. $3 C$ ). However, most of the IL- $1 \alpha$ detectable by ELISA eluted at $\mathrm{NaCl}$ concentrations $(65-80 \mathrm{mM} \mathrm{NaCl})$ lower than those required for elution of the IL-1 ra. Only when the IL- $1 \alpha$ levels dropped below the limit of detection was IL-1 inhibitory activity observed in fractions that contained ELISAdetectable IL-1 ra protein. The amount of IL- $1 \alpha$ (Fig. $3 C$ ) in
$\mathbf{A}$

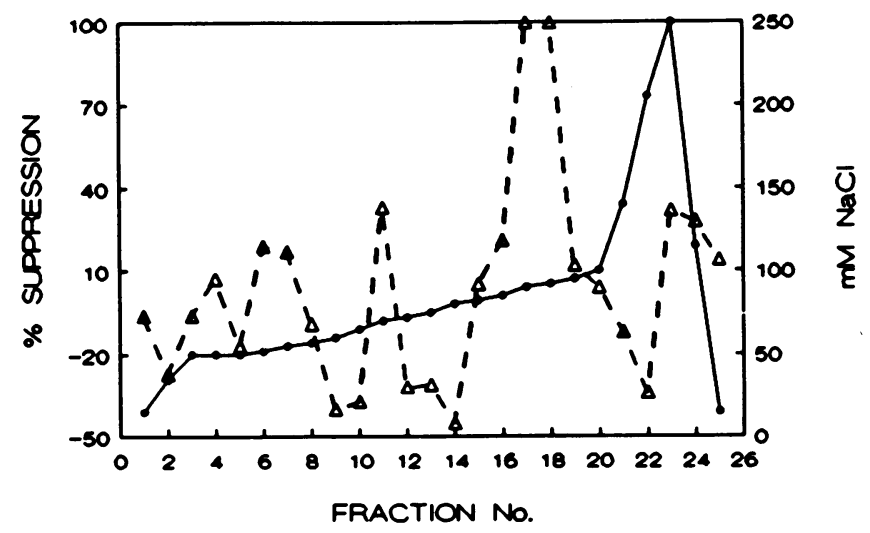

$\mathbf{B}$

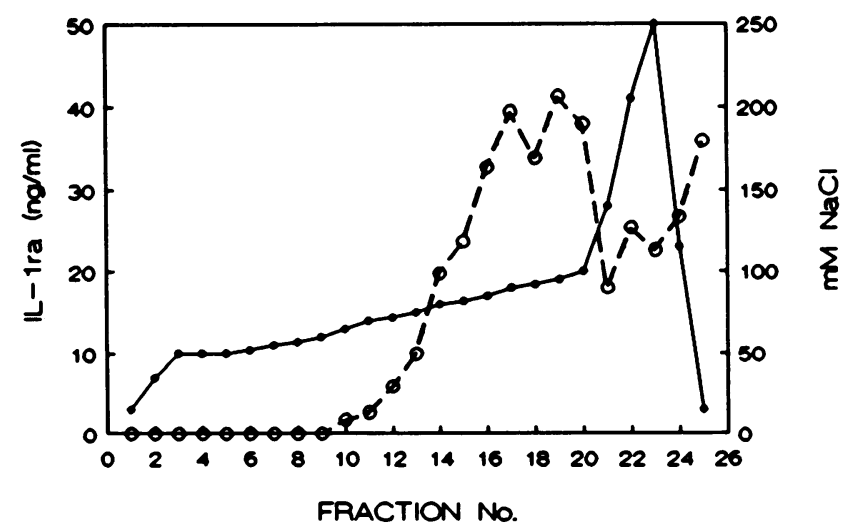

C

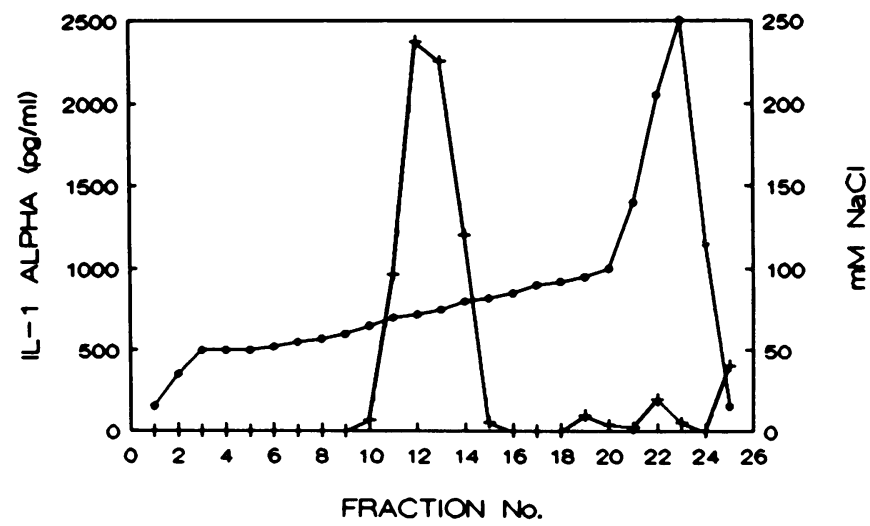

Figure 3. Fractionation of normal keratome cytosol by FPLC ion-exchange chromatography on a Mono $\mathrm{Q}$ column. $A-C$ are described in the Fig. 2 legend. The $\mathrm{NaCl}$ gradient ( $\mathrm{mM}$ ) is indicated on the right ordinate.

fractions 19-25 would appear to be too high to allow detection of IL-1 inhibitory activity (Fig. $3 A$ ) by the IL-1 ra protein shown to be present in these fractions (Fig. $3 B$ ).

$I L-1$ ra in psoriatic epidermal cytosol. Unfractionated cytosol from clinically stable psoriatic lesions displays a pattern of IL-1 inhibitory activity that differs from the pattern observed in unfractionated cytosol from normal epidermis (Fig. 4). Un- 


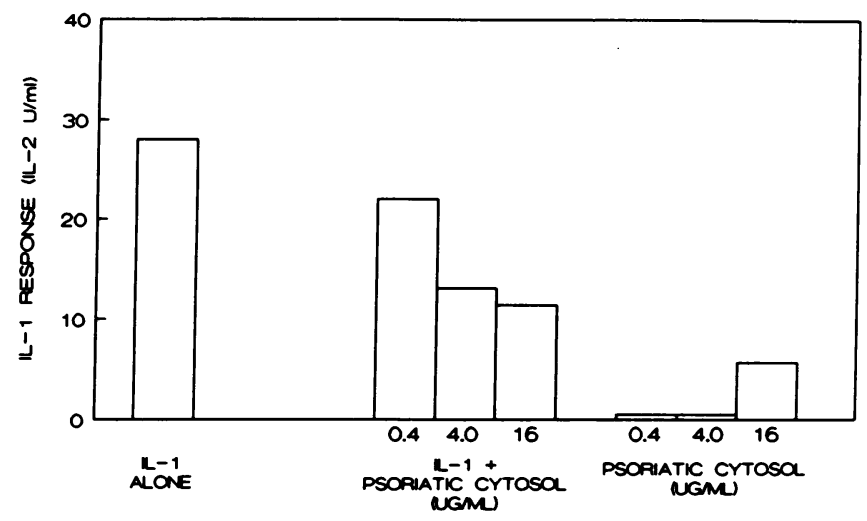

Figure 4. IL-1 and IL-1 inhibitory activities are present in keratome cytosol from psoriatic-involved skin. The first bar indicates activity of $0.25 \mathrm{U} / \mathrm{ml} \mathrm{IL-1}$ beta alone. Bars 2-4 indicate detected IL-1 activity where $0.25 \mathrm{U} / \mathrm{ml} \mathrm{IL}-1 \beta$ was mixed with the indicated concentrations of psoriatic keratome cytosol. Bars 5-7 show the endogenous IL-1 activity in the keratome cytosol in the absence of added IL- $1 \beta$.

like normal cytosol, IL-1 activity was observed in psoriatic cytosol only at concentrations $>4 \mu \mathrm{g} / \mathrm{ml}$. In addition, the IL-1 inhibitory activity at these higher concentrations was not complete. These results again point toward a complex set of interactions among cytokines with synergistic stimulatory action and inhibitory action in crude unfractionated cytosols.

To determine whether IL-1 ra is present in clinically stable involved psoriatic epidermal cytosol, fractionations were performed similar to those described for cytosols from normal skin. In contrast to normal skin, size fractionation alone revealed the presence of IL-1 inhibitory activity (Fig. $5 \mathrm{~A}$ ). Indeed, as detected by ELISA, IL-1 ra protein coeluted with IL-1 inhibitory activity in a major peak of $30 \mathrm{kD}$ (Fig. $5 B$ ). IL-1 $\alpha$ protein was only detected in a single fraction (Fig. $5 C$ ), confirming that little IL- $1 \alpha$ was present in the psoriatic keratome cytosol (30). The relative lack of IL- $1 \alpha$ in the psoriatic fractions $(200 \mathrm{pg} / \mathrm{ml}$ in a single fraction $)$ as compared to the abundant amounts of IL- $1 \alpha$ in the normal fractions (400-2,800 $\mathrm{pg} / \mathrm{ml}$ in nine fractions) likely accounts for the ease of detection of IL-1 inhibitory activity in psoriatic cytosols.

To further characterize the IL-1 inhibitors in psoriatic skin, keratome cytosol from lesional epidermis was separated by anion exchange chromatography. A large peak of IL-1 inhibitory activity eluted at a similar $\mathrm{NaCl}$ concentration (Fig. 6) as was observed with normal skin (Fig. 3). The volume of ion-exchange fractions from the psoriatic skin cytosols was not sufficient to permit performance of ELISAs for IL-1 ra and IL- $1 \alpha$ proteins.

Epidermal IL-1 inhibitory activity is neutralizable by an anti-IL-1 ra protein $m A b$. To determine whether the IL-1 inhibitory activity that coeluted with the IL-1 ra protein from normal skin is indeed due to a functional IL-1 ra molecule, antibody neutralization of the Mono $Q$ fractions ( 17 and 18) containing IL-1 inhibitory activity and ELISA-detectable IL-1 ra protein was performed (Table I). Addition of $0.25 \mathrm{U} / \mathrm{ml}$ of IL-1 to LBRM.33 cells resulted in release of $8.9 \mathrm{U} / \mathrm{ml}$ of IL-2. Addition of normal keratome cytosol fractions containing IL-1 inhibitory activity (Mono $Q$ fractions 17 and 18 ) resulted in $100 \%$ inhibition of LBRM.33 stimulation by IL-1 $(0 \mathrm{U} / \mathrm{ml}$ IL-2 release). Addition of a neutralizing mAb against IL-1 ra

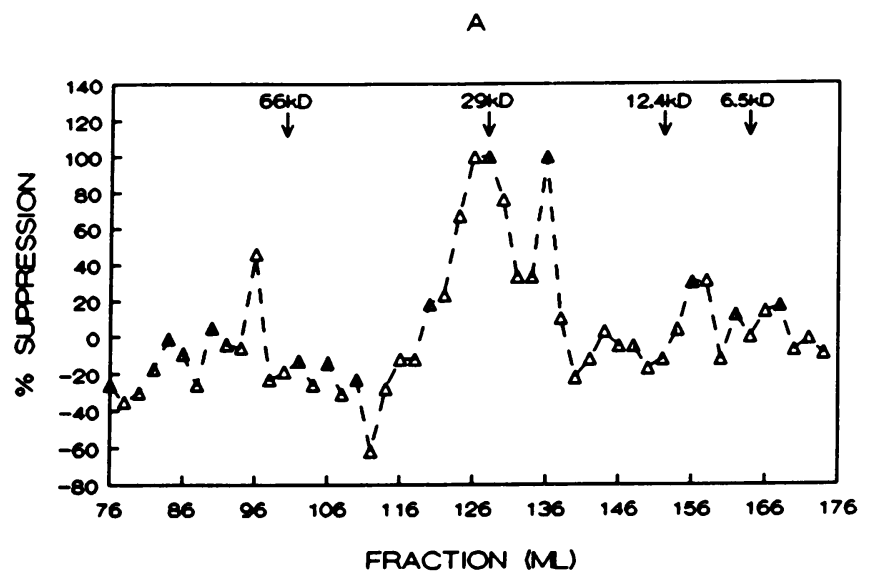

B
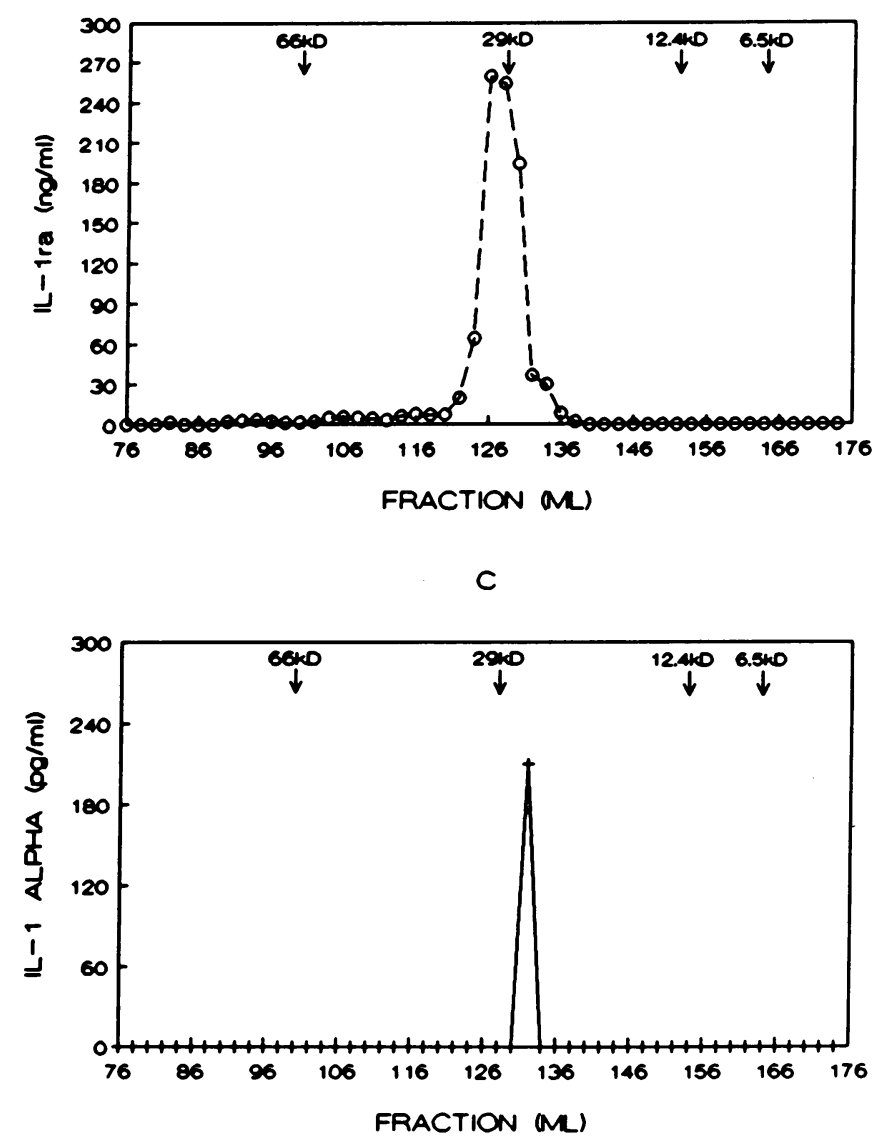

Figure 5. IL-1 inhibitor bioactivity and IL-1 ra protein are present in involved psoriatic keratome cytosol. This cytosol was fractionated by a TSK G2000SW sizing column and fractions analyzed for $(A)$ IL-1 inhibitor bioactivity, $(B)$ IL-1 ra protein, and $(C)$ IL-1 $\alpha$ protein.

protein at dilutions of $1: 25$ and $1: 50$ resulted in complete neutralization of the IL-1 inhibitory activity as evidenced by the release of 10.5 and $9.4 \mathrm{U} / \mathrm{ml}$ of IL-2, respectively. A mAb isotype control, 1D.116, which is capable of neutralizing TGF $\beta$ activity, did not affect the IL-1 inhibitory activity in these fractions ( 0 units IL-2 release).

A similar result was obtained with Mono $Q$ fractions 14,15 , and 16 from involved psoriatic skin that contained IL-1 inhibi- 


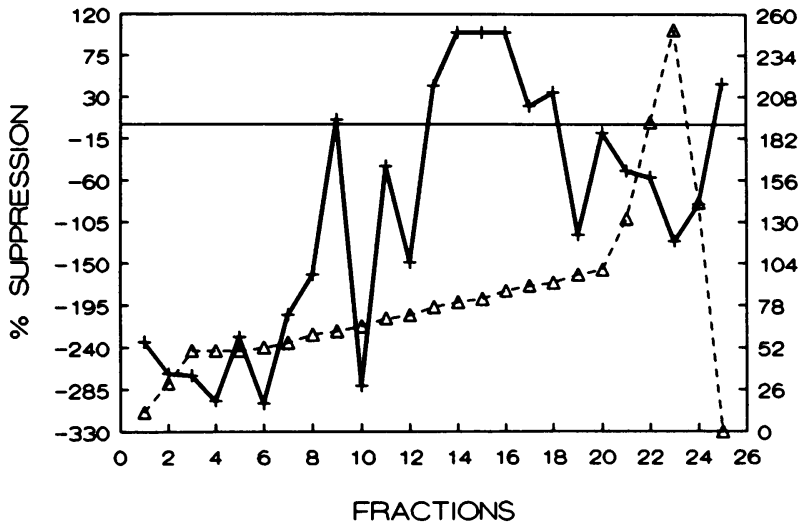

Figure 6. Fractionation of involved psoriatic keratome cytosol by FPLC ion exchange chromatography on a Mono $Q$ column. The left ordinate depicts the percent suppression of IL-2 production by IL-1induced LBRM. 33 cells; the right ordinate shows the $\mathrm{NaCl}$ gradient in $\mathrm{mM}$, and the abscissa represents the column fractions. The horizontal line indicates $0 \%$ suppression of IL-1 bioactivity; all data points above this line represent inhibition of IL-1 activity.

tory activity. In this experiment addition of $0.25 \mathrm{U} / \mathrm{ml}$ of rIL-1 resulted in the release of $16.9 \mathrm{U} / \mathrm{ml} \mathrm{IL-2}$ and this response was completely blocked by psoriatic cytosol (Table I). The IL-1 inhibitory activity of these fractions was completely neutral-

Table I. Monoclonal Antibody to IL-1ra Neutralizes IL-I Inhibitory Activity in Pooled Mono Q Fractions

\begin{tabular}{|c|c|c|}
\hline Addition to LBRM. 33 cells and PHA & IL-2 released* & IL-1 inhibition ${ }^{\ddagger}$ \\
\hline & $U / m l$ & $\%$ suppression \\
\hline IL-1 & 8.9 & - \\
\hline IL-1 + normal keratome fractions & 0 & $100 \%$ \\
\hline \multicolumn{3}{|l|}{ IL-1 + normal cytosol } \\
\hline+ anti-IL-1 ra $(1: 25)^{\S}$ & 10.5 & $<0$ \\
\hline \multicolumn{3}{|l|}{ IL-1 + normal cytosol } \\
\hline + anti-IL-1 ra (1:50) & 9.4 & $<0$ \\
\hline \multicolumn{3}{|l|}{ IL-1 + normal cytosol } \\
\hline+ anti-TGF $\beta(1: 25)^{\prime \prime}$ & 0 & $100 \%$ \\
\hline \multicolumn{3}{|l|}{ IL-1 + normal cytosol } \\
\hline+ anti-TGF $\beta(1: 50)$ & 0 & $100 \%$ \\
\hline IL-1 & 16.9 & - \\
\hline IL-1 + psoriatic keratome fractions & 0 & $100 \%$ \\
\hline \multicolumn{3}{|l|}{ IL-1 + psoriatic cytosol } \\
\hline+ anti-IL-1ra (1:25) & 28.4 & $<0$ \\
\hline \multicolumn{3}{|l|}{ IL-1 + psoriatic cytosol } \\
\hline+ anti-TGF $\beta(1: 25)$ & 0 & $100 \%$ \\
\hline
\end{tabular}

* Amount of IL-2 released as detected by 3-(4,5-dimethylthiazol-2yl)-2,5-diphenyltetrazolium bromide reduction by LBRM.33 cells cultured with a suboptimal concentration of rIL-1 $(0.25 \mathrm{U} / \mathrm{ml})$ in the absence or presence of Mono $Q$ fractions containing IL-1 inhibitory activity.

${ }^{\ddagger}$ IL-1 inhibition by cytosol fractions with or without antibodies is quantified as percent suppression of IL-2 release induced by $0.25 \mathrm{U} /$ $\mathrm{ml}$ of rIL-1.

${ }^{8}$ Anti-IL-1 ra ascites (I.10) was added to the mixture of IL-1, Mono Q fractions, PHA, and LBRM.33 cells at a dilution of 1:25.

"Anti-TFG $\beta$ ascites (1D.116) was added to the mixture of IL-1, Mono $\mathrm{Q}$ fractions, PHA, and LBRM.33 cells at a dilution of 1:25. ized by the mAb to IL-1 ra ( $28.4 \mathrm{U} / \mathrm{ml}$ IL-2 release $)$ but, again, unaffected by the neutralizing antibody to TGF $\beta$. Further evidence that the IL-1 inhibitory activity from psoriatic skin was indeed due to IL-1 ra was the complete neutralization of IL-1 inhibitory activity in the major size-fractionated TSK G2000SW peak (Fig. $4 \mathrm{~A}$ ) in addition to unfractionated psoriatic cytosol by the anti-IL-1 ra mAb (data not shown).

IL-1ra protein in skin. Although IL-1 inhibitory activity was much more easily demonstrable in psoriatic relative to normal skin, it was possible that this result might not be due to increased IL- 1 ra but to reduced IL- $1 \alpha$. The amounts of IL- 1 ra and IL- $1 \alpha$ proteins in samples of unfractionated epidermal cytosols were therefore quantified by specific ELISAs and expressed per milligram of total protein. Normal skin extracts contained $73.9 \pm 15.6 \mathrm{ng}$ IL- $1 \mathrm{ra} / \mathrm{mg}$ protein and $0.6 \pm 0.4 \mathrm{ng}$ IL- $1 \alpha / \mathrm{mg}$ protein ( Table II). Uninvolved psoriatic skin exhibited levels of IL- $1 \mathrm{ra}, 78.6 \pm 14.6 \mathrm{ng} / \mathrm{mg}$ protein, and IL- $1 \alpha$, $1.3 \pm 1.2 \mathrm{ng} / \mathrm{mg}$ protein, that were similar to normal skin. However, the levels of both IL-1 ra and IL- $1 \alpha$ were lower in clinically stable involved psoriatic skin, with IL-1 ra present at 53.8 \pm 7.2 $\mathrm{ng} / \mathrm{mg}$ protein and IL- $\alpha$ present at $0.05 \pm 0.08 \mathrm{ng} / \mathrm{mg}$ protein. If the relative amounts of IL- 1 ra to IL- $1 \alpha$ are compared for normal (123), uninvolved (60.5), and involved (1,076) psoriatic skin, an approximate 10 -fold increase in the amounts of IL-1 ra to IL- $1 \alpha$ occurred in involved psoriatic relative to normal or uninvolved psoriatic epidermis (Table II). If the individual IL-1 ra/IL- $1 \alpha$ ratios within the three groups are compared, the increase in the involved psoriatic IL- $1 \mathrm{ra} / \mathrm{IL}-1 \alpha$ ratio is statistically significant upon comparison to normal $(P<0.0004)$ or uninvolved $(P<0.0007)$ epidermis by univariate one-way analysis of variance of log-transformed data. However, by the same statistical analysis the individual IL-1 ra/IL- $1 \alpha$ ratios of normal and uninvolved psoriatic epidermis were not statistically significantly different $(P=0.44)$.

Epidermal IL-1ra is similar in molecular weight to icIL$1 \mathrm{ra}$. Based upon size-fractionation chromatography of human keratome cytosol, the molecular mass of the epidermal IL-1 ra

Table II. Elevated IL-1ra/IL-1 $\alpha$ Ratios in Keratome Cytosols

\begin{tabular}{|c|c|c|c|}
\hline Sample & IL-1 ra (n)* & $\mathrm{IL}-1 \alpha(\mathrm{n})^{*}$ & IL-1 ra/IL- $1 \alpha^{\ddagger}$ \\
\hline \multicolumn{4}{|c|}{$n g / m g$ protein } \\
\hline Normal skin & $73.9 \pm 15.6(6)$ & $0.6 \pm 0.4(6)$ & 123 \\
\hline $\begin{array}{r}\text { Psoriatic skin, } \\
\text { uninvolved }\end{array}$ & $78.6 \pm 14.6(7)$ & $1.3 \pm 1.2(4)$ & 60.5 \\
\hline $\begin{array}{l}\text { Psoriatic skin, } \\
\text { involved }\end{array}$ & $53.8 \pm 7.2(6)$ & $0.05 \pm 0.08(6)$ & 1076 \\
\hline
\end{tabular}

* The concentrations of IL-1 ra and IL- $1 \alpha$ proteins in keratome cytosols from normal skin, uninvolved psoriatic skin, or involved psoriatic skin were determined by specific ELISAs. Data is expressed in terms of $\mathrm{ng}$ IL-1 ra or IL- $1 \alpha / \mathrm{mg}$ protein. The same samples were analyzed for each cytokine, except for three samples of psoriatic uninvolved epidermis that were able to be analyzed for IL-1 ra but were of insufficient volume to be simultaneously analyzed for IL-1 $\alpha$. Data represent mean $\pm \mathrm{SD}$ based upon the indicated sample numbers $(n)$. ${ }^{\ddagger}$ Ratio of IL-1 ra to IL- $1 \alpha$ based upon ng/mg protein of each protein in the keratome cytosol. Psoriatic involved vs normal, $P<0.0004$; psoriatic involved vs uninvolved, $P<0.0007$; psoriatic uninvolved vs normal $P=0.44$ by univariate one-way analysis of variance of log-transformed data. 


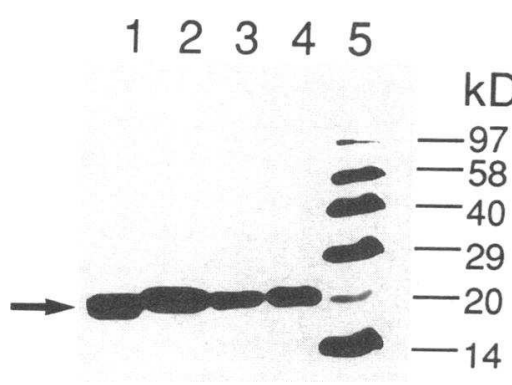

Figure 7. Western blot analysis of IL-1 ra protein using mAb I.5. The arrow indicates the migration of recombinant monocyte IL-1 ra in bar 1. Bar 2 contains cultured keratinocyte lysate, bar 3 involved psoriatic keratome cytosol, bar 4 normal keratome cytosol, and bar 5 mol wt markers.

would appear to be $\sim 30 \mathrm{kD}$ (Figs. 2 and 5 ). This is larger than the 17-kD (nonglycosylated) and 22-25-kD (glycosylated) sizes reported for the secreted IL-1 ra protein obtained from activated monocytes or the $20-\mathrm{kD}$ intracellular IL-1 ra protein expressed by in vitro-cultured keratinocytes and lung epithelia (38). A comparison of the sizes of IL-1 ra proteins from extracts of normal cultured keratinocytes and keratome cytosols was made to recombinant monocyte IL-1 ra protein by immunoblotting after separation on SDS-PAGE (Fig. 7). The epidermal-derived IL-1 ra from both normal and involved psoriatic skin migrated at $20 \mathrm{kD}$ by SDS-PAGE, the same size as keratinocyte IL-1 ra. Both the epidermal and keratinocyte IL1 ra protein migrated slightly larger than the recombinant IL1 ra protein derived from monocytes (secreted IL-1 ra), suggesting that IL-1 ra protein produced by epidermal keratinocytes in vivo represents the intracellular splice variant of IL-1 ra.

IL-I ra mRNA in normal and psoriatic skin. To evaluate the relative expression of mRNAs for the secreted and intracellular forms of IL-1 ra in normal and involved psoriatic skin, PCR analysis was performed. Both normal and clinically stable involved psoriatic skin expressed mRNA for the intracellular (Fig. $8 \mathrm{~A}$ ) and secreted (Fig. $8 \mathrm{~B}$ ) forms of IL-1 ra. However,

\section{$\begin{array}{llllllll}1 & 2 & 3 & 4 & 5 & 6 & 7 & 8\end{array}$}
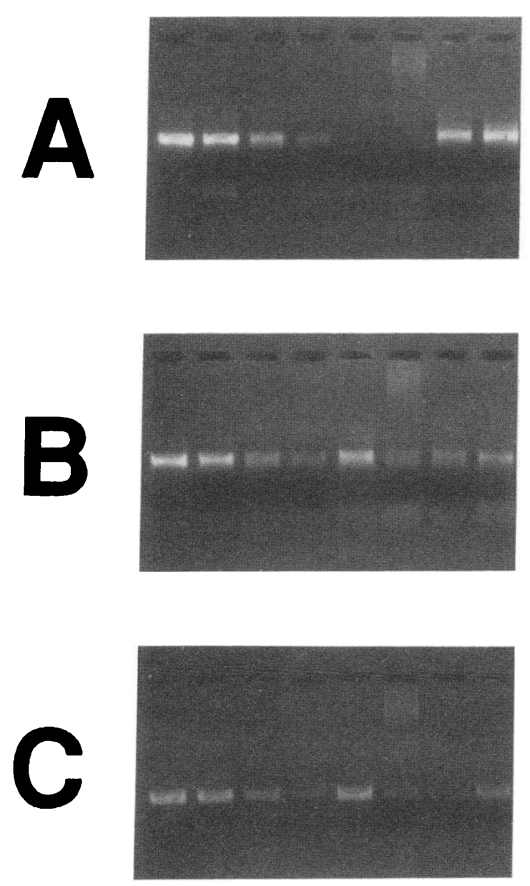

Figure 8. $(A)$ Intracellular IL-1 ra, $(B)$ secreted IL-1 ra, and $(C)$ IL-1 $\beta$ mRNAs as detected by PCR in normal and psoriatic keratomes. Bars 1-4 are the standard curve, ranging from 14 to $0.014 \mathrm{pg} / \mathrm{ml}$. Bar 5 contains total RNA from 4-h adherent monocytes, bar 6 nonadherent monocytes, bar 7 normal keratome, and bar 8 psoriatic involved keratome. only involved psoriatic skin had sufficient mRNA levels for IL- $1 \beta$ as detected by PCR (Fig. $8 C$ ). This is similar to our previous observation of increased IL- $1 \beta$ mRNA levels in involved psoriatic skin relative to normal skin (30). Monocytes did not express detectable amounts of mRNA for the intracellular form of IL-1 ra (Fig. $8 \mathrm{~A}$ ), but contained mRNA for both secreted IL-1 ra (Fig. $8 \mathrm{~B}$ ) and IL-1 $\beta$ (Fig. $8 \mathrm{C}$ ). Densitometer readings of these gels showed that mRNA levels in both normal and involved psoriatic skin for intracellular IL-1 ra (Fig. $9 \mathrm{~A}$ ) were $\sim 10$-fold greater than the mRNA levels for secreted IL$1 \mathrm{ra}($ Fig. $9 \mathrm{~B}$ ). These results also indicate that the mRNA levels for both IL-1 ra forms were higher in psoriatic involved skin relative to normal skin. Of note, the mRNA levels of secreted IL-1 ra in monocytes ( Fig. 9 B) compared with IL-1 $\beta$ (Fig. $9 C$ ) were approximately equal.

Differential expression of the IL-1ra molecule in psoriatic and normal skin. Because our epidermal extracts of keratome biopsies represent an average value of all epidermal cells, we next determined whether IL-1 ra was preferentially expressed in various epidermal compartments. Reaction of anti-IL-1 ra
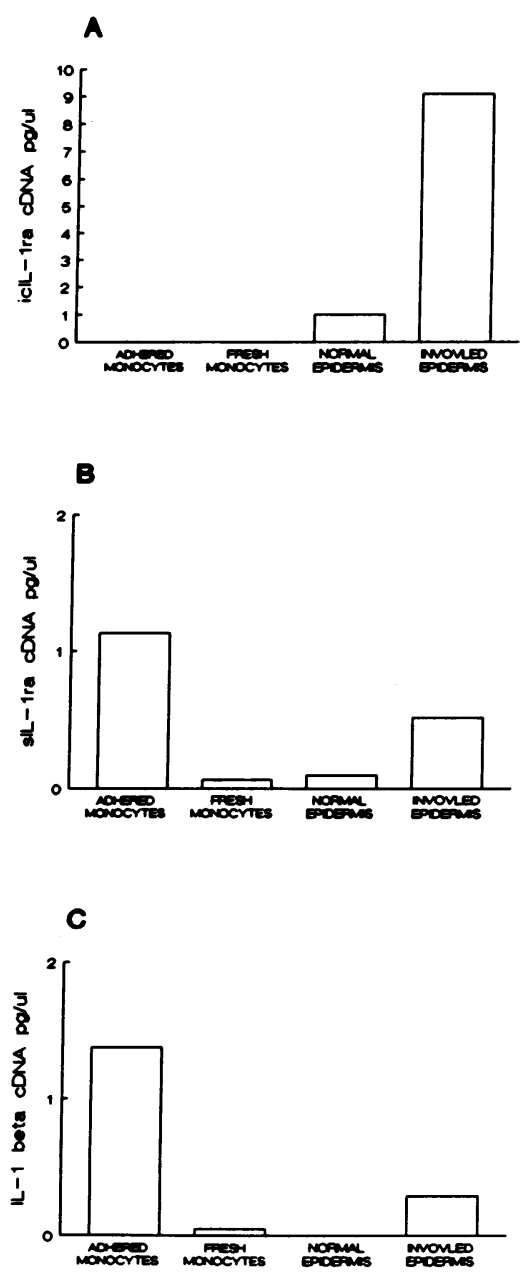

Figure 9. Amount of cDNA present in PCR products shown in Fig. 8. Densitometer readings were performed upon each sample and the appropriate cDNA standard curve. Based upon the standard curve the amount of cDNA in each reverse-transcribed sample was determined and expressed in $\mathrm{pg} / \mu \mathrm{l}$. Intracellular IL-1 ra, secreted IL-1 ra, and IL- $1 \beta$ values are given in $A, B$, and $C$, respectively. 

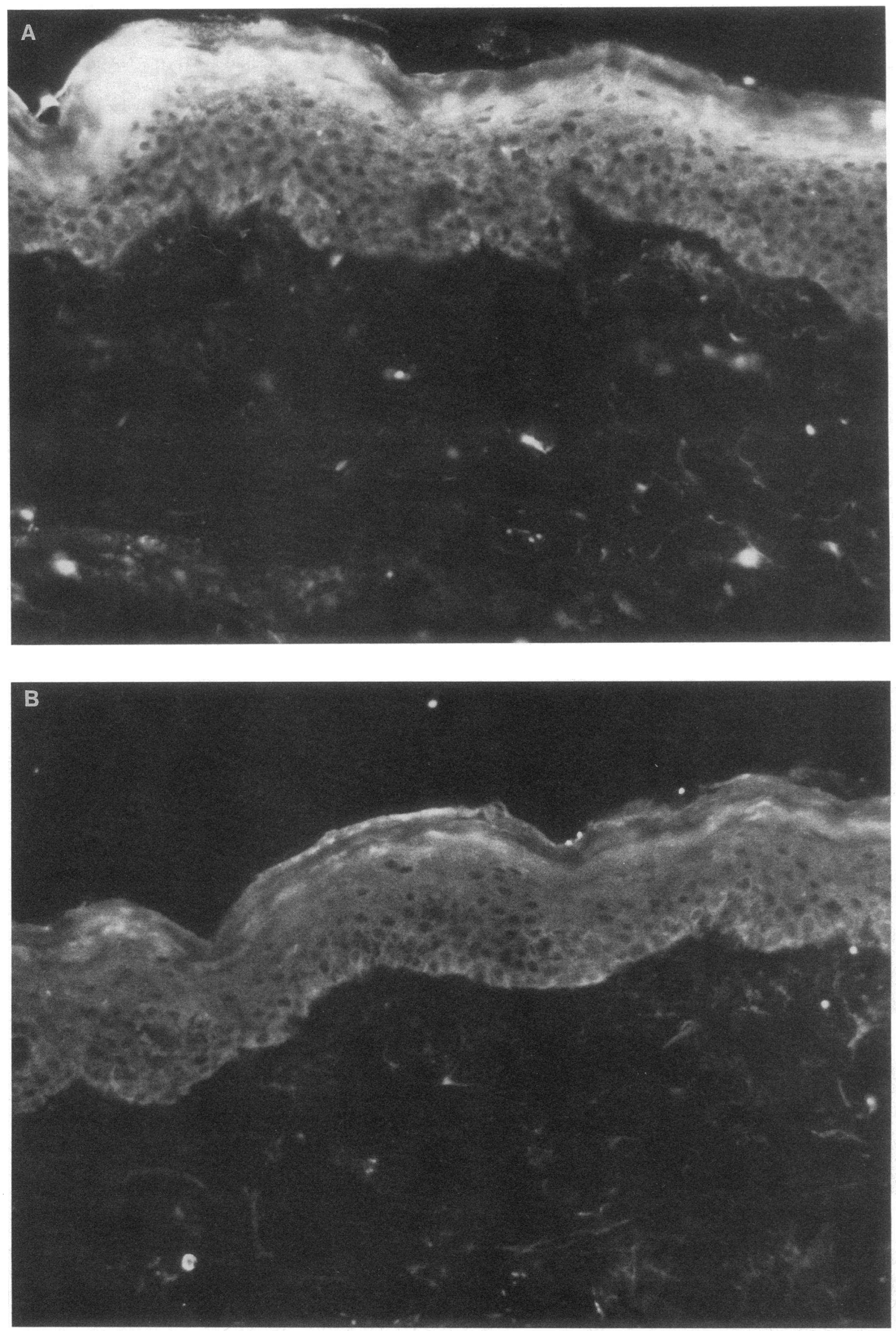

Figure 10. Localization of IL-1 ra protein in normal and psoriatic skin by indirect immunofluorescence. Normal skin reacted with $(A)$ anti-IL-1 ra mAb I.4 or $(B)$ I.4 preincubated with soluble recombinant IL-1 ra. Psoriatic involved skin stained with $(C)$ I.4 or $(D)$ I.4 preincubated with soluble recombinant IL-1 ra. Psoriatic uninvolved skin stained with $(E)$ I.4 or $(F)$ I.4 preincubated with soluble recombinant IL-1 ra (original magnification $\times 50$ ). 

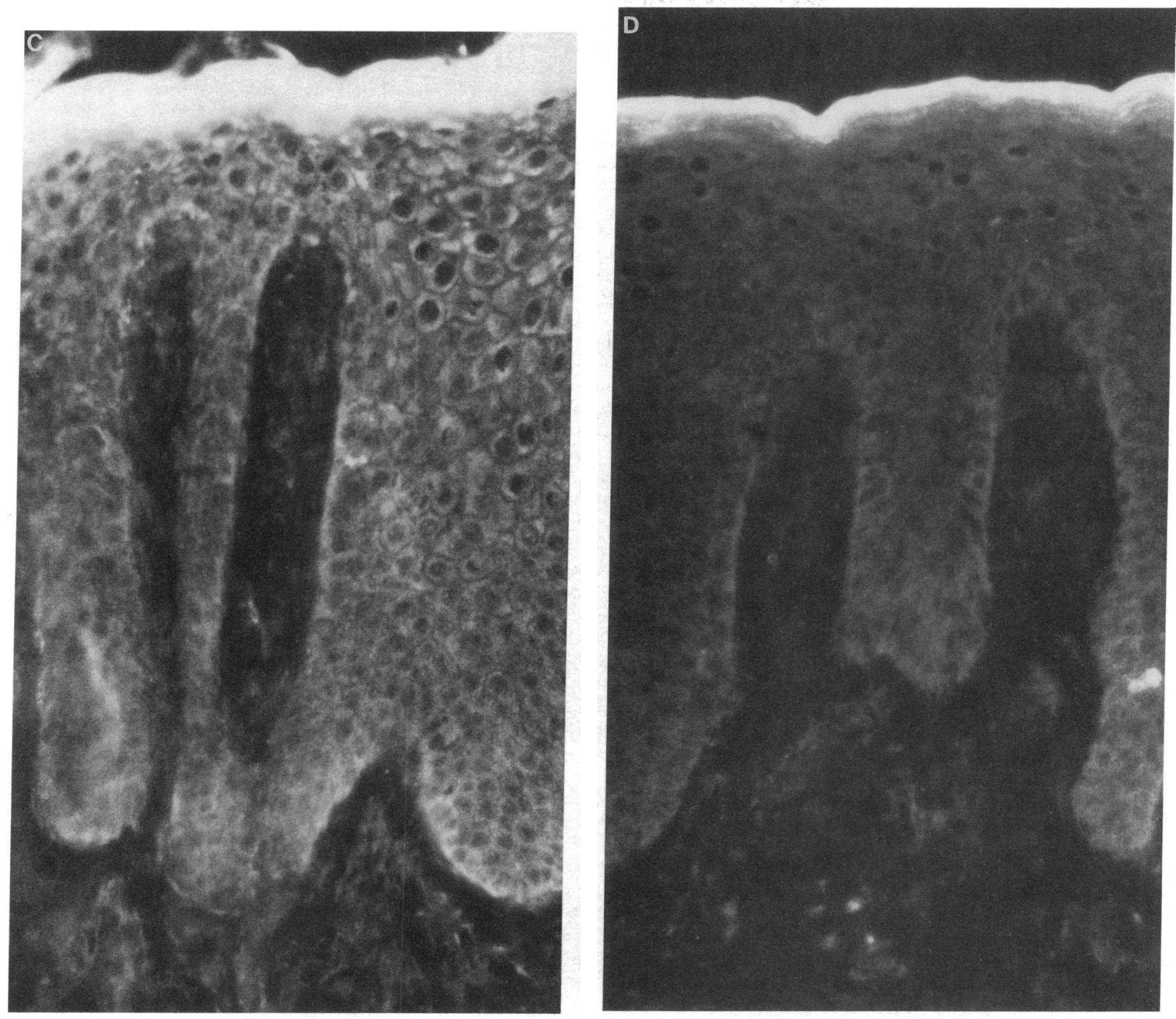

Figure 10 (Continued)

mAbs $\mathrm{I} .4$ or I.10 against normal epidermis resulted in heavy staining of the cytoplasm of keratinocytes located in the stratum granulosum but in minimal staining of the basal and midepidermis (Fig. $10 A$ ). This reactivity could be absorbed by preincubation with soluble recombinant IL-1 ra (Fig. $10 \mathrm{~B}$ ). This layer of the epidermis is associated with the expression of a number of genes associated with terminal differentiation of keratinocytes. In contrast to the stratum granulosum staining of normal skin, the greatest intensity of staining by I.4 against epidermis from clinically stable psoriatic lesions occurred in the basal-midbasal layers (Fig. $10 \mathrm{C}$ ). In lesional psoriatic skin, these compartments contain not only an increased population of cells in cell cycle, but also undergo accelerated differentiation as indicated by their expression of genes not normally expressed until the stratum granulosum $(47,48)$.

When the anti-IL-1 ra mAb I.4 was reacted with epidermis from uninvolved psoriatic skin, a reactivity pattern intermediate between normal and involved psoriatic skin was observed (Fig. $10 E$ ). Heavy staining was observed in both differentiat- ing midepidermal cells and basal cells, as well as in basal cells of the elongated rete pegs and papillary tips. As occurred in normal epidermis, preincubation of the $\mathrm{mAb}$ with soluble recombinant IL-1 ra blocked the reactivity patterns observed in psoriatic involved (Fig. $10 \mathrm{D}$ ) or uninvolved (Fig. $10 \mathrm{~F}$ ) epidermis. Nonspecific staining of the stratum corneum in psoriatic involved and uninvolved skin was revealed by the inability of soluble recombinant IL-1 ra to block this staining (Fig. 10, D and $F$ ) and by visualization of an identical staining pattern using the MOPC 21 isotype control antibody (data not shown). Of additional note was the occurrence of unidentified dermal cells in lesional psoriatic skin that express IL-1 ra (Fig. $10 C)$.

\section{Discussion}

The results of our studies indicate that IL-1 ra is present in both normal and psoriatic epidermis. The epidermal IL-1 ra had a molecular mass of $20 \mathrm{kD}$ by SDS-PAGE and an apparent mo- 

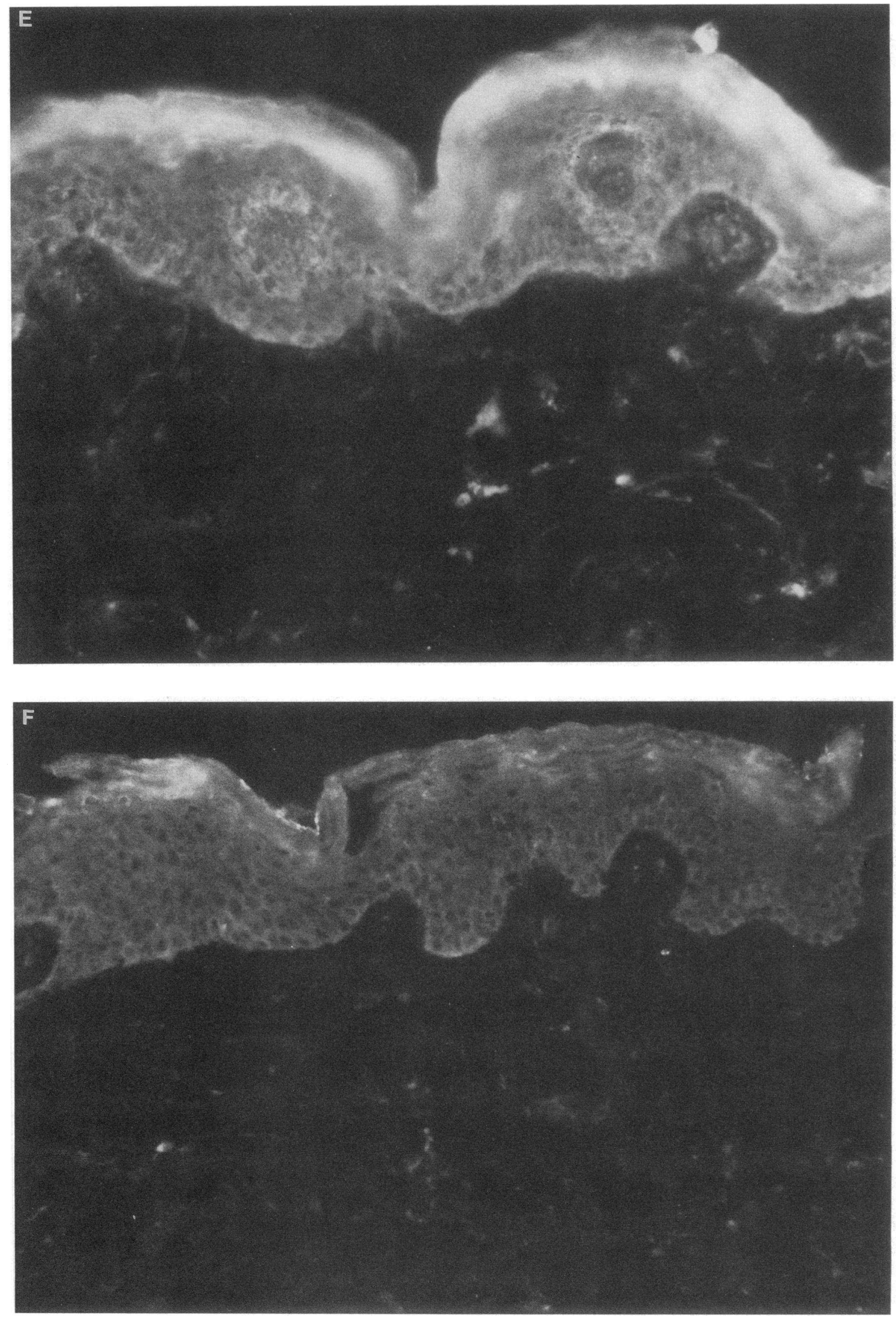

Figure 10 (Continued) 
lecular mass of $30 \mathrm{kD}$ by gel-filtration chromatography, likely because of the tendency of silica-based columns to retard movement of hydrophobic proteins such as IL-1. Although other keratinocyte-derived inhibitors of IL- 1 activity have been described, $(49,50)$ their size $(40$ and $50 \mathrm{kD}[49,50]$, respectively) and more basic pI (8.8) (49) distinguish them from the IL-1 ra activity described here. The size of the protein, as determined by SDS-PAGE, would indicate that epidermal IL-1 ra is similar to the intracellular IL-1 ra produced by cultured keratinocytes (38) and is slightly larger than the $17-\mathrm{kD}$ nonglycosylated form of monocyte IL-1 ra $(32,33,38)$. However, extracellular monocyte-derived IL-1 ra is primarily in the $22-25-\mathrm{kD}$ glycosylated form $(32,33)$. The absence of this size form in keratinocyte lysates or conditioned media (39) or in epidermal keratome cytosols as shown in these studies suggests that epidermal IL-1 ra is not glycosylated to any significant degree. Furthermore, the absence of the coding region for a leader peptide in the cDNA sequence for intracellular IL-1 ra would predict that this molecule would remain inside the cells; indeed this molecule is not detected in the medium of cultured keratinocytes untreated or treated with UV light $\left(100 \mathrm{~mJ} / \mathrm{cm}^{2}\right)$ (not shown).

PCR analysis revealed the presence in normal skin of mRNAs for both the monocyte and keratinocyte variants of IL-1 ra. Both forms were also present in involved psoriatic epidermis, although in greatly increased amounts and with the mRNA for the keratinocyte variant of IL-1 ra exceeding by a factor of 10 the mRNA for the monocyte form. However, given the possible problems with using PCR to quantitate mRNA these numbers should not be taken as absolute. Since cultured keratinocytes contain only the mRNA for the intracellular form of IL-1 ra (38), the mRNA for the monocyte variant found in the epidermis by PCR may be derived from Langerhans or other cells. That the $17-\mathrm{kD}$ monocyte-derived protein was not found in normal or psoriatic keratome cytosols by Western blot analysis may be due to the relative insensitivity of this technique. Alternatively, the mRNA for the monocyte variant of IL-1 ra may be present in skin with little to no protein translated. The in situ immunofluorescence staining of IL-1 ra protein did not resolve the differences in sIL-1 ra expression obtained by Western blot analysis and PCR analysis, since the antibodies recognize a common sequence and cannot distinguish between the two forms.

The overall IL-1 ra levels were lower in psoriatic epidermis from clinically stable plaques as compared with normal epidermis. However, the decrease in psoriatic IL-1 ra levels was not as extreme as that observed for IL- $1 \alpha(30)$, resulting in a 10 -fold increase in the amount of IL-1 ra relative to IL- $1 \alpha$ in psoriatic lesions compared with normal skin $(P<0.0004)$. The epidermal IL-1 ra levels may represent both the monocyte and keratinocyte variants of this molecule. Antisera are not yet available to discriminate between these two forms of IL-1 ra. Another major difference between psoriatic and normal epidermis is the location of the IL-1 ra protein as revealed by indirect immunofluorescence. IL-1 ra protein in normal epidermis is localized predominantly in the stratum granulosum. In psoriatic epidermis from clinically stable plaques, the intense band of IL-1 ra staining in the granular layer disappears and is replaced with a more homogeneous staining pattern in the squamous cell and granular layers. In addition, the psoriatic lesions showed increased presence of IL-1 ra protein in the basal to midbasal layers. This pattern resembles changes in differentiation that have been reported for involucrin and transglutaminase in epidermal cells in vivo. These molecules are normally expressed in the more differentiated cells of the stratum granulosum but in psoriasis are present in cells above the basal layer $(47,48,51)$. IL-1 $\alpha$, the IL-1 molecule that is present in the highest amount in the epidermis (30), has also been detected throughout the epidermis ( 52). However, IL- $1 \alpha$ may be compartmentalized to a region of normal epidermis reciprocal to IL-1 ra, as polyclonal anti-IL-1 $\alpha$ antibodies preferentially react with the basal cell layer (53).

The increased expression of IL-1 ra protein in the lower levels of lesional psoriatic epidermis may represent activation of IL-1 ra in concert with other terminal differentiation-associated proteins. The signals that induce accelerated terminal differentiation and epidermal growth in clinically stable lesions of psoriasis are increasingly being attributed to cytokines released as a result of immune activation of cells (54-58). Increased numbers $(22,23,59)$ and activity $(55-58,60)$ of skininfiltrating $T$ lymphocytes, antigen-presenting cells $(24,61)$, cytokines $(62,63)$, phospholipase $\mathrm{C} /$ protein kinase $\mathrm{C}-$ mediated cellular signals $(64)$, and growth factors $(54,65)$ have been implicated in the maintenance of the characteristic features of this disease. In addition, these factors may influence the altered epidermal differentiation $(47,48,66,67)$ and the increased keratinocytic, endothelial, and dendritic cell proliferation characteristic of psoriatic lesions (25-27).

Alternatively, increased expression of the intracellular IL1 ra protein may be a driving force for altered keratinocyte differentiation in psoriasis. The intracellular nature of both the IL-1 ra protein (38) and IL- $\alpha$ and IL- $1 \beta$ (13) produced by epidermal cells suggests that the IL-1 ra protein may play an intracellular role in regulating keratinocyte responses to cytoplasmic constitutively produced IL-1. This regulation may even be occurring in the nucleus because IL-1 has been detected in the nucleus of keratinocytes (30). Haskill et al. (38) proposed that the intracellular IL-1 ra may antagonize IL-1 by binding to IL-1 receptors possibly present on the nuclear membrane (68).

The involvement of IL-1 in regulating keratinocyte growth is controversial, with either potentiating (20) or inhibitory effects (69) being observed when IL-1 is incubated with cultured human keratinocytes. The discrepancy between these observations could be due to differences in culture conditions. Ristow (29) showed that IL-1 alone is not directly mitogenic for keratinocytes, but, in the in vivo milieu of multiple cytokines and growth factors, extracellular IL-1 does appear to be a growth promoter. Varying the concentration of intracellular (keratinocyte) IL-1 ra relative to IL-1 in keratinocytes may provide an additional level of control of keratinocyte growth. An imbalance in the icIL-1 ra/IL- $1 \alpha$ ratio could be another exacerbating factor resulting in the maintenance of the hyperproliferative state or accelerated differentiation of keratinocytes in clinically stable psoriatic plaques.

In conclusion, we demonstrated that normal human epidermis constitutively produces an IL-1 inhibitor and that this inhibitor is identical to a mRNA splicing variant (38) of the monocyte-derived IL-1 receptor antagonist cloned by Eisenberg et al. (34) and Carter et al. (33). This variant lacks a leader sequence for secretion (38) and thereby resides intracellularly in unperturbed human epidermis, predominantly in cells un- 
dergoing terminal differentiation in the stratum granulosum. Our initial finding that an IL-1 inhibitory bioactivity was elevated in clinically stable psoriatic epidermis can now be accounted for by the observations that this activity represents intracellular IL-1 ra protein expressed aberrantly in lower layers of lesional epidermis in association with markedly decreased IL- $1 \alpha$ levels. Understanding the events leading to alterations in the ratio of IL-1 ra and IL-1 in cells as well as the functional consequences of such alterations will yield important information on intracellular effects of such potent cytokines as IL-1.

\section{Acknowledgments}

The authors thank Dennise P. Calkins, Lily Chow, and Teri Whisenand for their excellent technical assistance.

These studies were supported by NIH grants AR39950 (W. P. Arend), AR40135 (W. P. Arend), AR01770 (K. D. Cooper), AR39691 (G. J. Fisher), AI26774 (J. S. Haskill), the Dermatology Foundation (C. Hammerberg), the Veterans Administration (K. D. Cooper), the Ella M. and Duncan O. Poth Fellowship (L. S. Chan), the Babcock Foundation, the Helen K. and Arthur E. Johnson Foundation (W. P. Arend), and an NIH training grant (L. S. Chan).

\section{References}

1. Gahring, L. C., A. Buckley, and R. A. Daynes. 1986. Presence of epidermalderived thymocyte activating factor/interleukin-1 in normal human stratum corneum. J. Clin. Invest. 76:1585-1591.

2. Hauser, C., J.-H. Saurat, J. A. Schmitt, F. Jaunin, and J. H. Dayer. 1986. Interleukin-1 is present in normal human epidermis. J. Immunol. 136:33173322.

3. Luger, T. A., B. M. Stadler, S. I. Katz, and J. J. Oppenheim. 1981. Epidermal cell (keratinocyte)-derived thymocyte-activating factor (ETAF). J. Immunol. 127:1493-1498.

4. Sauder, D. N., C. S. Carter, S. I. Katz, and J. J. Oppenheim. 1982. Epidermal cell production of thymocyte activating factor (ETAF). J. Invest. Dermatol. 79:34-39.

5. Reitamo, S., H. S. I. Anttila, L. Didierjean, and J.-H. Saurat. 1990. Immunohistochemical identification of interleukin 1 alpha and beta in human eccrine sweat-gland apparatus. Br. J. Dermatol. 122:315-323.

6. Dowd, P. M., R. D. R. Camp, and M. W. Greaves. 1988. Human recombinant interleukin-1 alpha is proinflammatory in normal human skin. Skin Pharmacol. 1:30-37.

7. Murphy, G. M., P. M. Dowd, B. N. Hudspith, J. Brostoff, and M. W. Greaves. 1989. Local increase in interleukin-1-like activity following UVB irradiation of human skin in vivo. Photodermatology. 6:268-274.

8. Granstein, R. D., and D. N. Sauder. 1987. Whole-body exposure to ultraviolet radiation results in increased serum interleukin-1 activity in humans. Lymphokine Res. 6(3):187-193.

9. Ansel, J. C., T. A. Luger, and I. Green. 1983. The effect of in vitro and in vivo UV irradiation on the production of ETAF activity by human and murine keratinocytes. J. Invest. Dermatol. 81:519-523.

10. Araneo, B. A., T. Dowell, H. B. Moon, and R. A. Daynes. 1989. Regulation of murine lymphokine production in vivo. Ultraviolet radiation exposure depresses IL- 2 and enhances IL- 4 production by T cells through an IL-1-dependent mechanism. J. Immunol. 143:1737-1744.

11. Mizutani, H., R. Black, and T. S. Kupper. 1991. Human keratinocytes produce but do not process pro-interleukin-1 (IL-1) beta. Different strategies of IL-1 production and processing in monocytes and keratinocytes. J. Clin. Invest. 87:1066-1071.

12. Hammerberg, C., G. Fisher, J. J. Voorhees, and K. D. Cooper. 1990. Human epidermis processes both IL-1 alpha and IL-1 beta into novel molecular isoforms. J. Invest. Dermatol. 94:532A. (Abstr.)

13. Kupper T. S., A. O. Chua, P. Flood, J. McGuire, and U. Gubler. 1987. Interleukin 1 gene expression in cultured human keratinocytes is augmented by ultraviolet irradiation. J. Clin. Invest. 80:430-436.

14. Dinarello, C. A. 1989. Interleukin-1 and its biologically related cytokines. Adv. Immunol. 44:153-205.

15. Dayer, J. M., B. de Rochemonteix, B. Burrus, S. Demczk, and C. A. Dinarello. 1986. Human recombinant interleukin 1 stimulates collagenase and prostaglandin E2 production by human synovial cells. J. Clin. Invest. 77:645648.
16. Schmidt, J. A., S. B. Mizel, D. Cohen, and I. Green. 1982. Interleukin 1, a potential regulator of fibroblast proliferation. J. Immunol. 128:2177-2182.

17. Leeuwenberg, J. F. M., E. J. U. Von Asmuth, T. M. A. A. Jeunhomme, and W. A. Buurman. 1990. IFN-gamma regulates the expression of the adhesion molecule ELAM-1 and IL-6 production by human endothelial cells in vitro. $J$. Immunol. 145:2110-2114.

18. Pober, J. S., M. P. Bevilacqua, D. L. Mendrick, L. A. Lapierre, W. Fiers, and M. A. Gimbrone, Jr. 1986. Two distinct monokines, interleukin 1 and tumor necrosis factor, each independently induce biosynthesis and transient expression of the same antigen on the surface of cultured human vascular endothelial cells. $J$. Immunol. 136:1680-1687.

19. Ristow, H. J. 1987. A major factor contributing to epidermal proliferation in inflammatory skin diseases appears to be interleukin 1 or a related protein. Proc. Natl. Acad. Sci. USA. 84:1940-1944.

20. Sauder, D. N., B. M. Stanulis-Praeger, and B. A. Gilchrest. 1988. Autocrine growth stimulation of human keratinocytes by epidermal cell-derived thymocyte-activating factor: implications for skin aging. Arch. Dermatol. Res. 280:71-76.

21. Hammarstrom, S., M. Hamberg, B. Samuelsson, E. A. Duell, M. Stawiski, and J. J. Voorhees. 1975. Increased concentrations of nonesterified arachidonic acid, 12L-hydroxy-5,8,10,14-eicosatetraenoic acid, prostaglandin E2, and prostaglandin F2a in epidermis of psoriasis. Proc. Natl. Acad. Sci. USA. 72:5130-5134.

22. Stingl, G., K. Wolff, E. Diem, G. Baumgartner, and W. Knapp. 1977. In situ identification of lymphoreticular cells in benign and malignant infiltrates by membrane receptor sites. J. Invest. Dermatol. 69:231-235.

23. Baker, B. S., A. F. Swain, L. Fry, and H. Valdimarsson. 1984. Epidermal T lymphocytes and HLA-DR expression in psoriasis. Br. J. Dermatol. 110:555564.

24. Baadsgaard, O., A. K. Gupta, R. S. Taylor, C. N. Ellis, J. J. Voorhees, and K. D. Cooper. 1989. Psoriatic epidermal cells demonstrate increased numbers and function of non-Langerhans antigen-presenting cells. $J$. Invest. Dermatol. 92:190-195.

25. Braverman, I. M., and J. Sibley. 1982. Role of the microcirculation in the treatment and pathogenesis of psoriasis. J. Invest. Dermatol. 78:12-17.

26. Morganroth, G. S., L. S. Chan, G. D. Weinstein, J. J. Voorhees, and K. D. Cooper. 1991. Proliferating cells in psoriatic dermis are comprised primarily of T cells, endothelial cells, and factor XIIIa+ perivascular dendritic cells. J. Invest. Dermatol. 96:333-340.

27. Weinstein, G. D., and P. Frost. 1968. Abnormal cell proliferation in psoriasis. J. Invest. Dermatol. 50:254-259.

28. Sackstein, R., V. Falanga, J. W. Streilein, and Y. H. Chin. 1988. Lymphocyte adhesion to psoriatic dermal endothelium is mediated by a tissue-specific receptor/ligand interaction. J. Invest. Dermatol. 91:423-428.

29. Ristow, H.-J. 1990. Interleukin-1 does not stimulate DNA synthesis of cultured human keratinocytes growth-arrested in growth-factor-depleted medium. J. Invest. Dermatol. 95:688-692.

30. Cooper, K. D., C. Hammerberg, O. Baadsgaard, J. T. Elder, L. S. Chan, D. N. Sauder, J. J. Voorhees, and G. Fisher. 1990. IL-1 activity is reduced in psoriatic skin: decreased IL-1 alpha and increased non-functional IL-1 beta. $J$. Immunol. 144:4593-4603.

31. Kim, N-I., K. D. Cooper, G. Fisher, O. Baadsgaard, J. J. Voorhees, and C. Hammerberg. 1992. Psoriatic skin reveals the in vivo presence of an epidermal IL-1 inhibitor. Arch. Dermatol. Res. 284:71-76.

32. Hannum, C. H., C. J. Wilcox, W. P. Arend, F. G. Joslin, D. J. Dripps, P. L. Heimdal, L. G. Armes, A. Sommer, S. P. Eisenberg, and R. C. Thompson. 1990. Interleukin-1 receptor antagonist activity of a human interleukin-1 inhibitor. Nature (Lond.). 343:336-340.

33. Carter, D. B., M. R. Deibel, Jr., C. J. Dunn, C.-S. C. Tomich, A. L. Laborde, J. L. Slightom, A. E. Berger, M. J. Bienkowski, F. F. Sun, R. N. McEwan, et al. 1990. Purification, cloning, expression and biological characterization of an interleukin-1 receptor antagonist protein. Nature (Lond.). 344:633638.

34. Eisenberg, S. P., R. J. Evans, W. P. Arend, E. Verderber, M. T. Brewer, C. H. Hannum, and R. C. Thompson. 1990. Primary structure and functional expression from complementary DNA of a human interleukin-1 receptor antagonist. Nature (Lond.). 343:341-346.

35. Arend, W. P., H. G. Welgus, R. C. Thompson, and S. P. Eisenberg. 1990. Biological properties of recombinant human monocyte-derived interleukin 1 receptor antagonist. J. Clin. Invest. 85:1694-1697.

36. Dripps, D. J., E. Verderber, R. K. Ng, R. C. Thompson, and S. P. Eisenberg. 1991. Interleukin-1 receptor antagonist binds to the Type II interleukin-1 receptor on B cells and neutrophils. J. Biol. Chem. 266:20311-20315.

37. Granowitz, E. V., B. D. Clark, J. Mancilla, and C. A. Dinarello. 1991. Interleukin-1 receptor antagonist competitively inhibits the binding of interleukin-1 to the Type II interleukin-1 receptor. J. Biol. Chem. 266:14147-14150.

38. Haskill, S., G. Martin, L. Van Le, J. Morris, A. Peace, C. F. Bigler, G. J. Jaffe, C. Hammerberg, S. A. Sporn, S. Fong et al. 1991. cDNA cloning of an intracellular form of the human interleukin-1 receptor antagonist associated with epithelium. Proc. Natl. Acad. Sci. USA. 88:3681-3685. 
39. Bigler, C. F., D. A. Norris, W. L. Weston, and W. P. Arend. 1992. Interleukin-1 receptor antagonist production by human keratinocytes. J. Invest. Dermatol. $98: 38-44$.

40. Malyak, M., F. G. Joslin, E. P. Verderber, S. P. Eisenberg, and W. P. Arend. 1991. IL-1 ra ELISA: reduction and alkylation of synovial fluid eliminates interference by IgM rheumatoid factors. J. Immunol. Methods. 140:281-288.

41. Kipps, T. J., and L. A. Herzenberg. 1986. Schemata for the production of monoclonal antibody-producing hybridomas. In Handbook of Experimental Immunology. D. M. Weir, editor. Blackwell Scientific Publications. Oxford, England. 108.

42. Boyce, S. T., and R. G. Ham. 1983. Calcium regulated differentiation of normal human epidermal keratinocytes in chemically-defined clonal cultures and serum-free serial cultures. J. Invest. Dermatol. 81 (Suppl):33-40.

43. Chan, L. S., C. Hammerberg, and K. D. Cooper. 1990. Cicatricial pemphigoid: identification of two distinct sets of epidermal antigens by IgA and IgG class circulating autoantibodies. Arch. Dermatol. 126:1466-1468.

44. Dasch, J. R., D. R. Pace, W. Waegell, D. Inenaga, and L. Ellingsworth 1989. Monoclonal antibodies recognizing transforming growth factor-beta. Bioactivity neutralization and transforming growth factor beta 2 affinity purification. J. Immunol. 142:1536-1541.

45. Kawasaki, E. A., and A. M. Wang. 1989. In PCR Technology. H. A. Erlich, editor. Stockton, New York. 89.

46. Wang, A. M., M. V. Doyle, and D. F. Mark. 1989. Quantitation of mRNA by the polymerase chain reaction. Proc. Natl. Acad. Sci. USA. 86:9717-9721.

47. Bernard, B. A., D. Asselineau, L. Schaffar-Deshayes, and M. Y. Darmon. 1988. Abnormal sequence of expression of differentiation markers in psoriatic epidermis: inversion of two steps in the differentiation program? J. Invest. Dermatol. 90:801-805.

48. Bernard, B. A., S. M. Robinson, S. Vandaele, J. N. Mansbridge, and M. Darmon. 1985. Abnormal maturation pathway of keratinocytes in psoriatic skin. Br. J. Dermatol. 112:647-653.

49. Schwarz, T., A. Urbanska, F. Gschnait, and T. A. Luger. 1987. UV-irradiated epidermal cells produce a specific inhibitor of interleukin I activity. $J$. Immunol. 138:1457-1463.

50. Kupper, T. S., and J. McGuire. 1986. Hydrocortisone reduces both constitutive and UV-elicited release of epidermal thymocyte activating factor (ETAF) by cultured keratinocytes. J. Invest. Dermatol. 87:570-573.

51. Bernard, B. A., A. Reano, Y. M. Darmon, and J. Thivolet. 1986. Precocious appearance of involucrin and epidermal transglutaminase during differentiation of psoriatic skin. Br. J. Dermatol. 114:279-283.

52. Didierjean, L., D. Salomon, Y. Merot, G. Siegenthaler, A. Shaw, J.-M. Dayer, and J.-H. Saurat. 1989. Localization and characterization of interleukin 1 immunoreactive pool (IL-1 alpha and beta forms) in normal human epidermis. J. Invest. Dermatol. 92:809-816.

53. Anttila, H. S. I., S. Reitamo, P. Erkko, A. Miettinen, L. Didierjean, and J.-H. Saurat. 1990. Membrane and cytosolic interleukin-1 alpha and beta in normal human epidermal cells: variability of epitope exposure in immunohistochemistry. J. Invest. Dermatol. 95:31-38.

54. Krueger, J. G., J. F. Krane, D. M. Carter, and A. B. Gottlieb. 1990. Role of growth factors, cytokines, and their receptors in the pathogenesis of psoriasis. $J$. Invest. Dermatol. 94:135S-140S.

55. Ellis, C. N., D. C. Gorsulowsky, T. A. Hamilton, J. K. Billings, M. D.
Brown, J. T. Headington, K. D. Cooper, O. Baadsgaard, E. A. Duell, T. M. Annesley et al. 1986. Cyclosporine improves psoriasis in a double-blind study. JAMA (J. Am. Med. Assoc.) 256:3110-3116.

56. Ellis, C. N., M. S. Fradin, J. M. Messana, M. D. Brown, M. T. Siegel, A. H. Hartley, L. L. Rocher, S. Wheeler, T. A. Hamilton, T. G. Parish et al. 1991. Cyclosporine for plaque-type psoriasis. Results of a multidose, double-blind trial. N. Engl. J. Med. 324:277-284.

57. Gottlieb, A. B., A. D. Luster, D. N. Posnett, and D. M. Carter. 1988 Detection of a gamma interferon-induced protein IP-10 in psoriatic plaques. $J$. Exp. Med. 168:941-948.

58. Baadsgaard, O., P. Tong, J. T. Elder, E. R. Hansen, V. Ho, C. Hammerberg, G. Lange-Vejlsgaard, D. A. Fox, G. Fisher, L. S. Chan et al. 1990. UM4D4+ (CDw60) T cells are compartmentalized into psoriatic skin and release lymphokines that induce a keratinocyte phenotype expressed in psoriatic lesions. J. Invest. Dermatol. 95:275-282.

59. Gupta, A. K., O. Baadsgaard, C. N. Ellis, J. J. Voorhees, and K. D. Cooper. 1989. Lymphocytes and macrophages of the epidermis and dermis in lesional psoriatic skin, but not epidermal Langerhans cells, are depleted by treatment with cyclosporin A. Arch. Dermatol. Res. 281:219-226.

60. Valdimarsson, H., B. S. Baker, I. Jonsdottir, and L. Fry. 1986. Psoriasis: a disease of abnormal keratinocyte proliferation induced by $\mathrm{T}$ lymphocytes. Immunol. Today. 7:256-259.

61. Cooper, K. D., O. Baadsgaard, C. N. Ellis, E. Duell, and J. J. Voorhees. 1990. Mechanisms of cyclosporine A inhibition of antigen-presenting activity in uninvolved and lesional psoriatic epidermis. J. Invest. Dermatol. 94:649-656.

62. Grossman, R. M., J. Krueger, D. Yourish, A. Granelli-Piperno, D. P. Murphy, L. T. May, T. S. Kupper, P. B. Sehgal, and A. B. Gottlieb. 1989. Interleukin 6 is expressed in high levels in psoriatic skin and stimulates proliferation of cultured human keratinocytes. Proc. Natl. Acad. Sci. USA. 86:6367-6371.

63. Sticherling, M., E. Bornscheuer, J.-M. Schroder, and E. Christophers 1991. Localization of neutrophil-activating peptide-1/interleukin-8-immunoreactivity in normal and psoriatic skin. J. Invest. Dermatol. 96:26-30.

64. Fisher, G. J., H. S. Talwar, A. Tavakkol, J. Esmann, J. J. Baldassare, J. T. Elder, C. E. M. Griffiths, O. Baadsgaard, K. D. Cooper, and J. J. Voorhees. 1990 Phosphoinositide-mediated signal transduction in normal and psoriatic epidermis. J. Invest. Dermatol. $95: 15 S-17 S$.

65. Elder, J. T., G. J. Fisher, P. B. Lindquist, G. L. Bennett, M. R. Pittelkow, R. J. Coffey, Jr., L. Ellingsworth, R. Derynck, and J. J. Voorhees. 1989. Overexpression of transforming growth factor alpha in psoriatic epidermis. Science (Wash. DC). 243:811-814.

66. Dover, R., and F. M. Watt. 1987. Measurement of the rate of epidermal terminal differentiation: expression of involucrin by S-phase keratinocytes in culture and in psoriatic plaques. J. Invest. Dermatol. 89:349-352.

67. Esmann, J., J. J. Voorhees, and G. J. Fisher. 1989. Increased membraneassociated transglutaminase activity in psoriasis. Biochem. Biophys. Res. Com mun. 164:219-224.

68. Grenfell, S., N. Smithers, K. Miller, and R. Solari. 1989. Receptor-mediated endocytosis and nuclear transport of human interleukin 1 alpha. Biochem. J. 264:813-822.

69. Morhenn, V. B., G. J. Wastek, A. B. Cua, and J. N. Mansbridge. 1989. Effects of recombinant interleukin 1 and interleukin 2 on human keratinocytes. J. Invest. Dermatol. 93:121-126. 